To cite this research paper:

Shubbak, M.H., 2018. Innovation capability, network embeddedness and economic performance: profiling solar power innovators in China. Int. Journal of Technological Learning, Innovation and Development. Vol. 10 (3-4), pp. 258-294. https://doi.org/10.1504/IJTLID.2018.093723.

\title{
Innovation Capability, Network Embeddedness and Economic Performance: Profiling Solar Power Innovators in China
}

\author{
Mahmood H. Shubbak \\ Faculty of Business Studies and Economics, \\ University of Bremen, \\ Hochschulring 4, 28359 Bremen, Germany \\ Email:shubbak@uni-bremen.de
}

\begin{abstract}
This paper discusses the technological upgrading of China in photovoltaics technology. It explores the patterns of innovation and network-embeddedness and their impact on economic performance at the firm level. Identifying the main innovators over 1995-2014 with patent and market-share indicators, the landscape of their activities is inspected through two hierarchical cluster analyses in parallel: First, against the quantity, quality and diversity of patents, and second, against global-integration, component-size and position in technological knowledge networks. The resulting clusters are cross-related to understand their interrelations with age, size, turnover and productivity of actors. The multivariate analysis of variance shows a significant relationship between innovation-network concurrency and the age, turnover and productivity. Globalintegration in small-world networks is significantly related with economic performance. Quality of innovation shows higher importance than quantity and diversity. While specialization in hightech fields has positive impact on turnover, production-oriented firms with low-tech focus have higher productivity.
\end{abstract}

\section{KEYWORDS}

innovation system; solar photovoltaics; China; patent profiles; network embeddedness patterns; cluster analysis; MANOVA; concurrency matrix; economic performance; productivity; technological upgrading; emerging economy

JEL CLASSIFICATION

D24; D85; O31; O34; Q42; Q55

\section{BIOGRAPHICAL STATEMENT}

Mahmood Shubbak is a researcher in the Faculty of Business Studies \& Economics at the University of Bremen. His research interests are related to innovation systems and technology upgrading of emerging economies. He obtained his $\mathrm{PhD}$ in Economics from the University of Bremen in 2018. He holds a Bachelor and Master degrees in Mechatronics, ICT and Automation Engineering. 


\section{INTRODUCTION}

Technological upgrading of emerging economies comprises multi-level structural change industrially, organisationally and technologically (Jindra, et al., 2015; Radosevic \& Yoruk, 2016). Throughout these processes, innovation can both lead to, and result from successful catching-up (Lee, 2013). Innovation has long been considered as a main driver of economic development at the macro-level (Schumpeter, 1934). Theoretically, it has been shown that within an industry, there is a significant correlation between innovative activities undertaken in companies and the financial performance measured by growth in assets, turnover, and productivity (Pavitt, 1963, p. 207). However, empirical findings about the relationship between innovation capability and firm performance on the microlevel have been mixed. While many studies validated a positive impact (Geroski \& Machin, 1992; Crepon, et al., 1998; Cainelli, et al., 2006; Andries \& Faems, 2013), others found no or even negative relationships (MacDonald, 2004; Artz, et al., 2010).

This suggests a puzzle, which we attempt to answer by inspecting the role of network embeddedness in shaping and facilitating the relationship between innovation and economic performance. An increasing consensus in the academic literature has recently emerged on the significant effect of embeddedness in interfirm networks on the innovative and economic performance of firms (Powell, et al., 1996; Gilsing, et al., 2008). In this paper, we will suggest that the impact of innovation capability on economic performance at the firm level is highly heterogeneous across different networkembeddedness patterns.

Accordingly, the paper aims to disentangle the combined effects of innovation-capability and network-embeddedness patterns on age, size, and financial performance of organisations. Considering the technological upgrading within the solar photovoltaics $(\mathrm{PV})$ industry in China, we address the following research questions:

- Which are the main actors in the Chinese PV innovation system? Which characteristics do they have?

- Which patterns of innovative activities and knowledge network embeddedness could be found in the system?

- What is the relationship between these patterns and economic performance?

To answer these questions, the paper is organized in six sections. The next section reviews the relevant literature. Section 3 introduces the research methodology, data sources and indicators used in the empirical analysis. In section 4, the results concerning main actors, innovation patterns, network patterns and concurrency analysis are presented. Section 5 synthesises the main empirical findings and tests the research hypotheses. Finally, section 6 draws some conclusions and highlights the research limitations.

Information Box: Broader Context and Conceptual Framework

To meet the challenges posed by climate change, renewable energy sources are widely considered as a clean and sustainable alternative to the conventional sources (fossil fuels). However, the differences in economic feasibility between both types (in terms of initial capital and megawatt-hour costs) have long constituted a key obstacle for renewable sources to become a major means of generating electricity at the global level. On the other hand, three parallel paths could interactively lead to the grid parity: - first, product and process innovations, second, mass production and vertical integration, and third, government 
subsidies for both supply and demand sides of renewable sources. While the latter two paths concern with reducing the manufacturing and operational costs, innovation is more related to increasing power conversion efficiency. To understand the interrelated roles of the three parallel paths, the use of the conceptual framework of innovation systems sounds reasonable.

\section{Technological Systems of Innovation:}

Innovation is not exclusively restricted inside firms, it is rather an outcome of active interrelations between various firm and non-firm entities within complex systems (Günther, 2015). The systemic approach of studying innovation was developed in the late 1980s at a national level (Freeman, 1988; Lundvall, 1992) and later, at sectoral and technological levels (Carlsson \& Stankiewicz, 1991; Breschi \& Malerba, 1997). The significance of this framework lies in its comprehensiveness and inclusion of all the important factors influencing innovation (Edquist, 1997). Carlsson \& Stankiewicz (1991, p. 111) defined technological innovation systems (TIS) as "network of agents interacting in a specific economic area under a particular institutional infrastructure... and involved in the generation, diffusion, and utilization of technology". From that perspective, TIS aims at understanding innovation by considering three analytical blocks - (1) the innovative actors, (2) the network structure of their interactions, (3) the institutional framework.

Nonetheless, given the instability and politics-dependent nature of government subsidizing programs ${ }^{1}$, innovation and mass production are considered more important for renewables to become competitive per se in the global energy market. Accordingly, the focus of this paper is on the characteristics of innovators (actors), their technological knowledge networks (interactions), and associated economic performance (productivity). The institutional framework of the TIS is out of the scope of this paper.

\section{THEORY AND HYPOTHESES}

\subsection{The Influence of Innovation Capability on Economic Performance}

The impact of innovative activities on economic performance has long been at the centre of the attention of many studies (Franko, 1989; Geroski \& Machin, 1992; Schmidt, 1995; Lester, 1998; Evangelista \& Vezzani, 2010; Hashi \& Stojčić, 2013; Adeyeye, et al., 2013). Cainelli, et al. (2006) found a significant positive impact of innovation on economic growth and productivity of firms. Andries \& Faems (2013) highlighted the positive contribution of innovation performance and patenting activities to the profit margins of both SMEs and large firms. Furthermore, Silva et al. (2017) shown a positive impact of technological innovation on firms' economic and strategic export performance. In this sense, we expect a positive impact of innovation capability of firms on their economic performance.

\section{Hypothesis 1a: The innovation capability of an organization is positively related} to its economic performance.

Malerba \& Orsenigo (1997) studied the sectoral patterns of innovative activities, showing that although turbulent innovative activities are fundamental for industrial evolution (creative destruction), persistent innovative activities by large established firms are also important for deepening technological capabilities (creative accumulation). They found that effective patterns of innovation depend mainly on the structural characteristics of the technology and its related learning processes. As innovative companies get bigger, they usually accumulate more technological knowledge, financial assets, and market experience becoming better able to invest in substantial research and development projects as well as to introduce more innovations. Therefore, we expect a positive 
relationship between companies' age and size on the one hand, and their innovation capability on the other. Stated more formally:

Hypothesis 1b: The age of an organization is positively related to its innovation capability.

Hypothesis 1c: The size of an organization is positively related to its innovation capability.

However, the sole consideration of the quantity of innovative activity throughput can be misleading. Further characteristics of innovation can be of a higher importance, such as its quality and diversity. Innovations of high quality can have a significant impact on the value and adoption rates of final products, and thus on the market share and revenue of their developers.

Sampson (2007) studied the impact of technological diversity and alliance organizational form on firm innovative performance highlighting the importance of alliances along with moderate technological diversity for innovation. Furthermore, Leten, et al. (2007) found an inverted U-shaped relationship between the technological diversification of a firm and its performance, where technological coherence plays a moderating role. While Hitt, et al. (1997) emphasized the importance of product diversification in moderating the negative effect of international diversification on firm performance at the first stage of internationalization, Lu \& Beamish (2004) showed positive net gains up to a certain point at the second phase of multinationalism. This leads to the following hypothesis:

Hypothesis 1d: The quality of innovation is more effective than its quantity and diversity in improving economic performance of organizations.

\subsection{The Influence of Network Embeddedness on Economic Performance}

An increasing unanimity in the literature has recently emerged on the significant effect of network-embeddedness on innovation and economic performance of organizations (Hagedoorn, 1993; Rowley, et al., 2000; Gilsing, et al., 2008). Ahuja (2000) showed that both direct and indirect ties between firms in collaboration networks within chemicals industry have positive impact on innovation. A similar significant relationship between embeddedness and innovation could be found in semiconductors industry (Stuart, 1998), steel industry (Rowley, et al., 2000), biotechnology (Powell, et al., 1996), and food manufacturing (Tsai, 2001).

Koka \& Prescott (2008, p. 658) argued that types of network positions are likely to impact firm performance differently under different contexts. Tsai (2001) found that occupying central network positions can provide organizational units with access to new knowledge developed elsewhere, which can yield more innovations and better economic performance, provided that these units have the necessary absorptive capacity. Gilsing, et al. (2008, p. 1729) argued that "position alone does not tell the full story", a successful outcome also depends on technological distance and network density. The results of (Uzzi, 1996) suggested that, up to a threshold point, network embeddedness could enhance economic effectiveness and competitiveness. Rowley (2000, p. 384) found that 
the strength of network ties influenced returns on assets contingent upon industry factors. Powell, et al. (1996) found positive impact of network diversity on firms' rate of growth. Goerzen \& Beamish (2005) stressed that firm strategies of either being focused in homogeneous networks, or having very diverse alliances, resulted in superior performance compared to the majority firms with moderate network diversity. Furthermore, as organizations get bigger, additional ties to their established networks are expected to be added, enhancing its embeddedness and network position (Wang, et al., 2018). In sum, this leads to the following hypotheses:

Hypothesis 2a: The network embeddedness of an organization is positively related to its economic performance.

Hypothesis 2b: Older organizations are more embedded in networks.

Hypothesis 2c: Larger organizations are more embedded in networks.

\subsection{The Combined Influence}

Although the effect of innovation and network embeddedness on economic performance is well established in academic literature, it is nonetheless only discussed on an individual basis. This leaves an important part of the image unclear. In other words, the combined effect of both dimensions is still to be addressed ${ }^{2}$. Considering the research gap introduced in section 1, we examine the following thesis: the different effects of innovation capability on economic outcome are attributed to different network structures or embeddedness levels. So that, we expect a positive effect of the interaction between innovation capability and network embeddedness on economic performance. Stated more formally:

Hypothesis 3: The innovation capability of an organization is more positively related to economic performance when the organization has a high network embeddedness level.

To test the hypotheses of this paper, a micro-level analysis is conducted within a specific technological field in a specific country, namely solar photovoltaics (PV) in China.

The contributions of this paper are threefold: First, it provides a detailed profiling of the main actors within the innovation system of PV technologies in China. Second, it uniquely defines two sets of patterns for both innovation-capability and networkembeddedness. Third, it introduces the novel analytical tool of 'concurrency matrix' to study the interaction between innovation and network patterns and its resulting impact on economic performance of firms.

\section{DATA AND METHODS}

Among the wide range of existing renewables, PV is considered as "the cleanest and safest technology with which to generate electricity even at the GW production scale" (Hegedus \& Luque, 2010, p. 24). China has recently become the main global player in both production and deployment of PV crystalline-silicon (c-Si) modules (UNEP, et al., 2010; Marigo, 2007). In 2008, it became the dominant force in PV production, controlling 
one-third of the global market (Fu, 2015). Later, since 2011, its market share has stabilized at the level of $60 \%$ (Jäger-Waldau, 2013). Furthermore, the country has experienced an exponential growth rate in terms of cumulative installed PV power since 2011, becoming the world's leader since 2015 with more than $43 \mathrm{GW}$, and reaching the level of $78 \mathrm{GW}$ in 2016 (British Petroleum, 2017).

Against this rapid growth of China's share in both supply and demand sides of PV, and being inspired by the importance of innovation, networking, and mass production processes in enhancing the stature of PV technologies in the global energy landscape, this paper studies the characteristics of the leading actors within the technological innovation system of PV in China using a combination of patent-, network-, and cluster analysis.

For the empirical analysis, patent data from PATSTAT (the Worldwide Patent Statistical Database) are mainly used. Pavitt (1985, p. 82) argued that patent statistics can be used as a proxy of innovative and not only inventive activities, considering the fact that they are usually filed "over the whole cycle of development and commercialisation of an innovation". Zahra \& George (2002) considered patent filings to evaluate the exploitation element of absorptive capacity at firm level. Despite the well-known limitation for using patents as a proxy for innovation (Archibugi, 1992; Kleinknecht, et al., 2002), patent statistics are, nonetheless, widely considered as the "best available output indicator" for innovation capability (Sawang, et al., 2017, p. 157; Freeman, 2004).

To extract PV relevant patent applications, we use the identification scheme developed by Shubbak (2017a). It offers a comprehensive definition of different technologies along the PV value chain. Using a classification scheme mainly based on IPC classes, Shubbak (2017a) defines six PV groups - solar cells, panels, electronics, monitoring, energy storage, and solar-powered portable devices. The scheme provides further detailed subgroups of the embodied technologies (see the technological subgroups in figure 4).

The quantitative analysis of this paper is carried out based upon four stages (figure 1):

\section{Identification of main actors}

In this stage, the main actors in the Chinese PV system of innovation are identified using patent and production data. The resulting list of innovators and active actors is thus compiled from the following sources:

- The largest purified-silicon feedstock producers in China with more than $1 \%$ share in the global market. [Data source: (Yu, et al., 2016; Roselund, 2016; Shubbak, 2017b)].

- The largest Chinese manufacturers of c-Si cells with more than 1\% share in the global market. [Renewable Energy World (Mints, 2014); dataset of (Brown, et al., 2015), and (Shubbak, 2017b)].

- The top 5\% transnational patent applicants, within the entire PV system, for inventions taken place in China. [PATSTAT 2015b based on (Shubbak, 2017a)].

- The top ten patent assignees for inventions within the main technological groups of the system (cell technologies, panels, and electronics). [PATSTAT 2015b based on (Shubbak, 2017a)]. 


\section{Figure1: Research Methodology Flowchart}

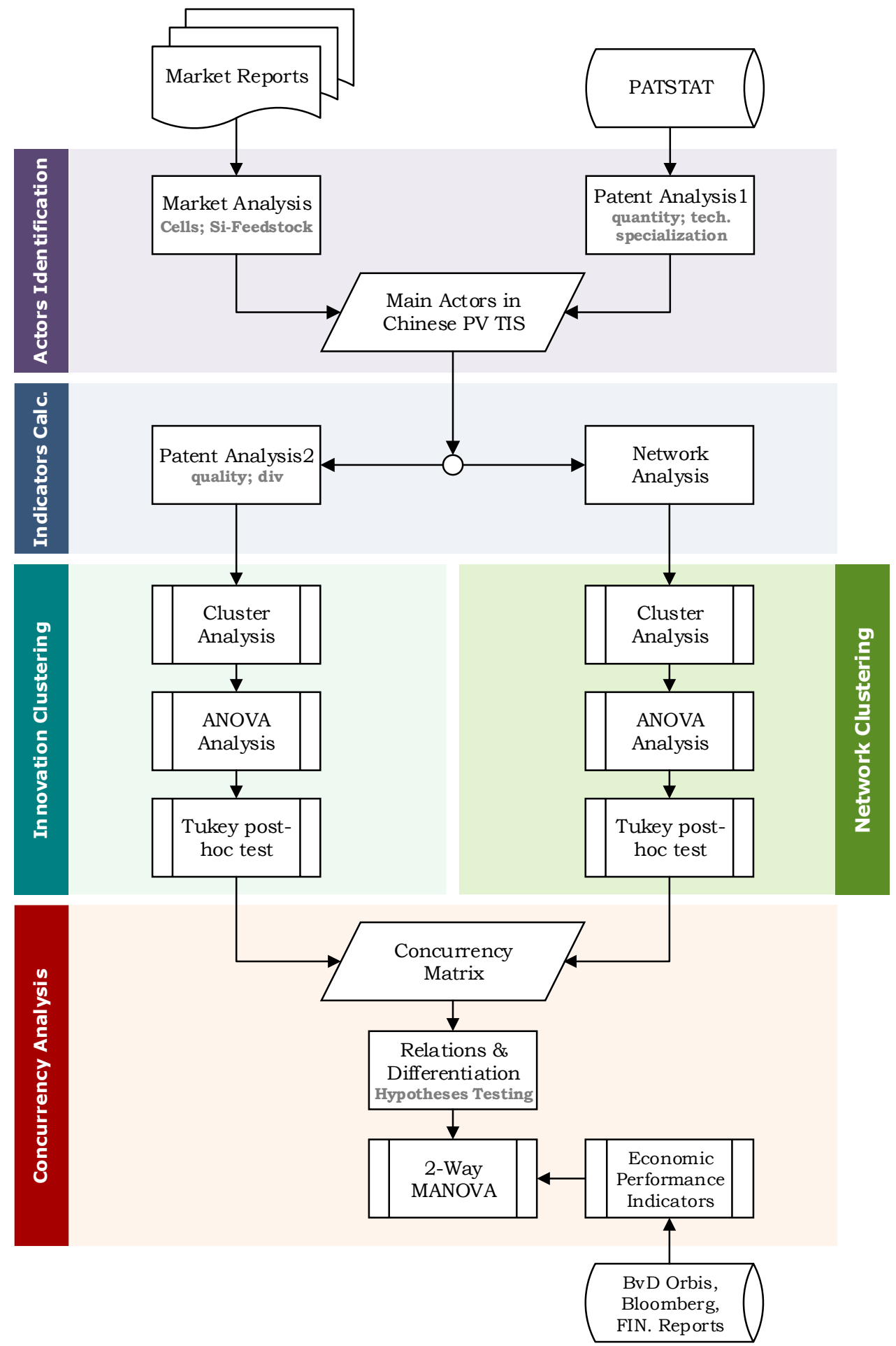

Author's own elaboration

\section{Calculation of indicators}

In this stage, quantitative measures of innovative performance and collaboration network embeddedness are calculated for each actor in the innovators list. This is done, first, through patent analysis of the quantity, quality, and diversification of inventive activities, and second, through social network analysis of actor positions and global integration in 
patent co-applicant networks. A full list of indicators and data sources used throughout this paper is contained in table 1 .

Table 1: Variable Definitions and Data Sources

\begin{tabular}{|c|c|c|}
\hline Variable & Description & Data Source \\
\hline \multicolumn{3}{|c|}{ Innovation Performance (Inventive Activities) } \\
\hline Pat & $\begin{array}{l}\text { Quantity: number of transnational patent applications filed by } \\
\text { an actor during 1995-2014 }\end{array}$ & \multirow{4}{*}{$\begin{array}{l}\text { PATSTAT } 2015 \mathrm{~b}, \\
\text { PV patents identified } \\
\text { and classified using } \\
\text { (Shubbak, 2017a) }\end{array}$} \\
\hline Fwd_Citn & $\begin{array}{l}\text { Quality1: Average of forward citations to the patents of an } \\
\text { actor over patent age. Proxy for techno-economic impact }\end{array}$ & \\
\hline High_tech & $\begin{array}{l}\text { Quality2: Percentage of high-tech patents of the total patent } \\
\text { applications filed by an actor }\end{array}$ & \\
\hline Div & Technological Diversification of patent applications of an actor & \\
\hline \multicolumn{3}{|c|}{ Network Embeddedness } \\
\hline Deg & $\begin{array}{l}\text { Weighted degree of actor node in the PV co-patenting network } \\
\text { in China over 1995-2014. Proxy for inventive collaboration }\end{array}$ & \multirow{5}{*}{$\begin{array}{l}\text { PATSTAT 2015b, } \\
\text { (Dominguez Lacasa } \\
\& \text { Shubbak, 2018) }\end{array}$} \\
\hline Btwn_cn & $\begin{array}{l}\text { Betweenness centrality of actor node in the PV co-patenting } \\
\text { network in China over 1995-2014. Proxy of actor's importance } \\
\text { for knowledge transfer over technological network }\end{array}$ & \\
\hline Clust_coef & $\begin{array}{l}\text { Clustering coefficient of actor node in the PV co-patenting } \\
\text { network in China over 1995-2014. Proxy for embeddedness in } \\
\text { small-world network }\end{array}$ & \\
\hline Com_Size & $\begin{array}{l}\text { Network component size: number of nodes in the component } \\
\text { (community) to which an actor belongs }\end{array}$ & \\
\hline Frgn_coll & $\begin{array}{l}\text { Collaboration with foreigner actors: percentage of non-Chinese } \\
\text { actors in network component to which an actor belongs }\end{array}$ & \\
\hline \multicolumn{3}{|c|}{ Characteristics and Economic Performance } \\
\hline Age & $\begin{array}{l}\text { Age of an actor: number of years since the establishment of an } \\
\text { actor till } 2015\end{array}$ & \multirow{4}{*}{$\begin{array}{l}\text { BvD Orbis database, } \\
\text { Bloomberg LP data; } \\
\text { Forbes lists; } \\
\text { Firm websites and } \\
\text { financial reports }\end{array}$} \\
\hline Turnover & $\begin{array}{l}\text { Economic performance: operating revenue (turnover) of an } \\
\text { actor in } 2015 \text { (values in million US dollars) }\end{array}$ & \\
\hline Employees & Size: number of employees of an actor in 2015 (in thousands) & \\
\hline Productivity & $\begin{array}{l}\text { Operating revenue over the number of employees. Proxy for } \\
\text { the efficiency of economic activities done by an actor }\end{array}$ & \\
\hline
\end{tabular}

With regard to the innovation dimension, the following variables were calculated:

The number of transnational patent applications (Pat) is used as a proxy for the quantity of innovation. It is calculated based on (Frietsch \& Schmoch, 2010) as the number of patent applications filed at the European Patent Office (EPO), and international patent applications filed under the Patent Cooperation Treaty (PCT), avoiding double counting of EPO applications at the international phase (equation 1).

$$
\text { Pat }=|T N| ; T N=\{x \mid x \in E P O \cup P C T\}
$$

The two types, EPO and PCT, are the only cross-border enforceable patents, and are thus expected to have high economic and technological value.

Forward citation index (Fwd_Citn) is used as a proxy for exogenous quality of innovation (technological impact of inventive activities). It is calculated for each actor as the average number of citations received $\left(C_{i}\right)$ over patent life time ${ }^{3}$ (age) for all transnational patent applications $(N)$ filed by the actor (equation 2 ). 


$$
F W d_{C i t n}=\frac{1}{N} \sum_{i=1}^{N} \frac{C_{i}}{a g e_{i}}
$$

The share of high-tech patents in the actor's portfolio (High-tech) is used as a proxy for endogenous quality of innovation. The indicator is based on (Shubbak, 2017a).

The technological diversification index (Div) reflects the extent to which an actor is engaged in inventive activities within several technological groups across the PV value chain (Leten, et al., 2007; Suominen, et al., 2017). It considers the diversity of patent portfolio of an actor calculated as the complement of normalized Herfindahl-Hirschman index (Hirschman, 1964) for patent shares $\left(s_{i}\right)$ of PV main groups $(N)$. (equation 3 )

$$
\operatorname{Div}=\frac{1}{N-1}\left(1-N \sum_{i=1}^{N} s_{i}^{2}\right)
$$

As for the network embeddedness dimension, the following indicators are considered ${ }^{4}$ :

The weighted degree ( $\mathrm{Deg})$ of an actor in network analysis represents the total number of ties that directly link the actor with its patent co-applicants. If two actors have more than one joint patent, the additional collaborations are added to their degrees. Consequently, this indicator reflects the total number of collaborations for each actor.

The betweenness centrality (Btwn_cn) of an actor reflects the importance of its position in connecting several components of the network, and thus in transferring knowledge. The indicator is measured as the fraction of shortest paths between other nodes in the network that pass through the designated node (Freeman, 1977). (equation 4)

$$
B t w n_{-} c n=\sum_{s \neq n_{i} \neq t} \frac{\sigma_{s t}\left(n_{i}\right)}{\sigma_{s t}}
$$

(Equation 4)

Where: s, t: represents any other nodes in the network; $\sigma_{s t}$ is the total number of shortest paths between $\mathrm{s}$ and $\mathrm{t} ; \sigma_{\mathrm{st}}\left(\mathrm{n}_{\mathrm{i}}\right)$ : is the number of shortest paths between $\mathrm{s}$ and that pass through the designated node $n_{i}$.

The size of network component (Com_size) is calculated as the number of nodes in the connected subgraph to which an actor belongs. It reflects the overall number of copatenting partners that are reachable by the actor either directly or indirectly.

The clustering coefficient (Clust_coef) of a node reflects the tendency of its neighbourhood to link together. It is measured as the ratio of existing links $\left(e_{i}\right)$ between a node's neighbours $\left(k_{i}\right)$ to the maximum possible links they could have (equation 5). High clustering coefficient is considered as an indicator for small-world networks.

$$
\text { Clust_coef }=\frac{2 e_{i}}{k_{i}\left(k_{i}-1\right)}
$$

Finally, the global integration indicator (Frgn_coll) reflects the ratio of collaborations between the designated actor and foreigner (non-Chinese) actors. It is calculated as the ratio of foreigners in the network component of the concerned actor.

For industrial actors which have no patent applications and thus not appearing in copatenting network, the diversity, centrality and clustering coefficients are set to -1 . 


\section{Cluster Analysis}

In this stage, the calculated indicators are used to assign actors into specific groups through two cluster analysis processes in parallel. The use of cluster analysis as a tool of discovery spans several disciplines in both natural and social sciences. Besides its use for pattern recognition, classification, and taxonomy construction, cluster analysis is widely used to reduce large complex datasets into meaningful homogeneous groups. The resulting groups can further serve as a basis for classifying new observations or developing inductive generalizations (Anderberg, 1973). Consequently, the purpose of cluster analyses in this paper is to explore the patterns of innovative activities (INNO) as well as the patterns of network embeddedness (NET) within the technological system of $\mathrm{PV}$, and to classify its main actors accordingly.

To do so, the four innovation-performance indicators are used in the first cluster analysis, while the five network-embeddedness variables are used in the second. Both cluster analysis are of hierarchical type, utilizing Ward's method, considering Euclidean distance as similarity measure, and normalizing variables to the 0-1 interval (Anderberg, 1973; Mooi \& Sarstedt, 2010).

The two cluster analyses are followed by robustness check of variance ratio criterion through one-way ANOVA. The purpose of this step is to insure significant differences among group mean values. Furthermore, a Tukey HSD (honest significant difference) post-hoc test is performed for better understanding of the resulting clusters and thus labelling them. All the statistical and cluster analysis operations throughout this paper are conducted using IBM SPSS Statistics, version 24.0. (IBM Corp., 2016).

\section{Co-evolution analysis (concurrency matrix and economic performance)}

In this stage both cluster sets are integrated into one concurrency matrix to study their interaction and confluence on economic performance of actors. Multivariate analysis of variance (MANOVA) is performed for this purpose, having actors' age, turnover, number of employees, and productivity as dependent variables.

The statistical general linear model of MANOVA is shown in equation 6 . Where $\mathrm{Y}_{\mathrm{ij}}$ represents the vector of observations for INNO treatments in NET blocks, $v$ is the overall mean vector, $\alpha_{\mathrm{i}}$ is the effect of INNO on the dependent variables, $\beta_{\mathrm{j}}$ is the effect of NET on the dependent variables, $\gamma_{\mathrm{ij}}$ is the non-additive effect of INNO*NET interaction on the dependent variables, and $\varepsilon_{\mathrm{ij}}$ is the experimental error vector.

$$
Y_{i j}=v+\alpha_{i}+\beta_{j}+\gamma_{i j}+\varepsilon_{i j}
$$

To insure a temporal order between the independent and dependent variables, the data for clustering variables spans from 1995 to 2014, while the general characteristic and economic performance indicators are considered for 2015. Nevertheless, it is worth stressing that causality is yet " $a$ logical and theoretical task that extends beyond the bounds of statistical analysis" (Grice \& Iwasaki, 2007, p. 201).

Finally, the complete image compiling the three analytical dimensions is illustrated in circular genome visualization using (Krzywinski, et al., 2009 ). 


\section{RESULTS}

\subsection{The Main Actors within the Chinese PV System}

Throughout the patent and market analysis conducted in this section, 37 organisations were identified as the main actors in the innovation system (table A1 in the appendix). Despite the relatively small size of this sample, the identified actors have however a prominent place within the system. They were accountable for $31 \%$ of global Si-feedstock production and 34\% of global c-Si cell manufacturing during 2010-2015. They held significant shares of the Chinese PV production in the same period, $60 \%$ of c-Si cells and $90 \%$ of feedstock. Furthermore, they were involved in co-patenting network components accountable for $41 \%$ of the overall Chinese transnational patent applications over 19952014. The detailed results are explained in the following subsections.

\subsubsection{Production and Market Share}

To identify the most active actors in the technological system of PV in China, the global markets of solar cells and purified silicon feedstock are first considered. c-Si is the dominant technology in the global market of solar PV. In 2015, it had 93\% share of the total produced capacity of PV cells. It also formed the main focus of Chinese production. However, among the manufacturing process of c-Si cells, the purification of polysilicon into solar-grade of $99.999 \%$ and its subsequent processes of ingot production are considered the core technology (Si-feedstock) (Mertens, 2014, pp. 99-102).

Figure 2 shows the market shares of global PV producers during 2010-2015. As illustrated in figure $2 \mathrm{a}$, the Si-feedstock global market is dominated by 14 firms sharing $91 \%$ of the 1.66 million metric ton market. Among those, 5 Chinese producers accountable for $31 \%$ share of the global market can be identified (underlined and shown in bold in figure 2a). On the other hand, the c-Si silicon cell market is more fragmented with the top 14 firms holding 55\% share of the $189 \mathrm{TWp}$ market (figure 2b). 6 Chinese manufacturers of solar cells with total market share of more than $30 \%$ are identified (underlined and in bold). 
Figure 2: Market Share of Global PV Producers 2010-2015

a. Global Si-Feedstock Production

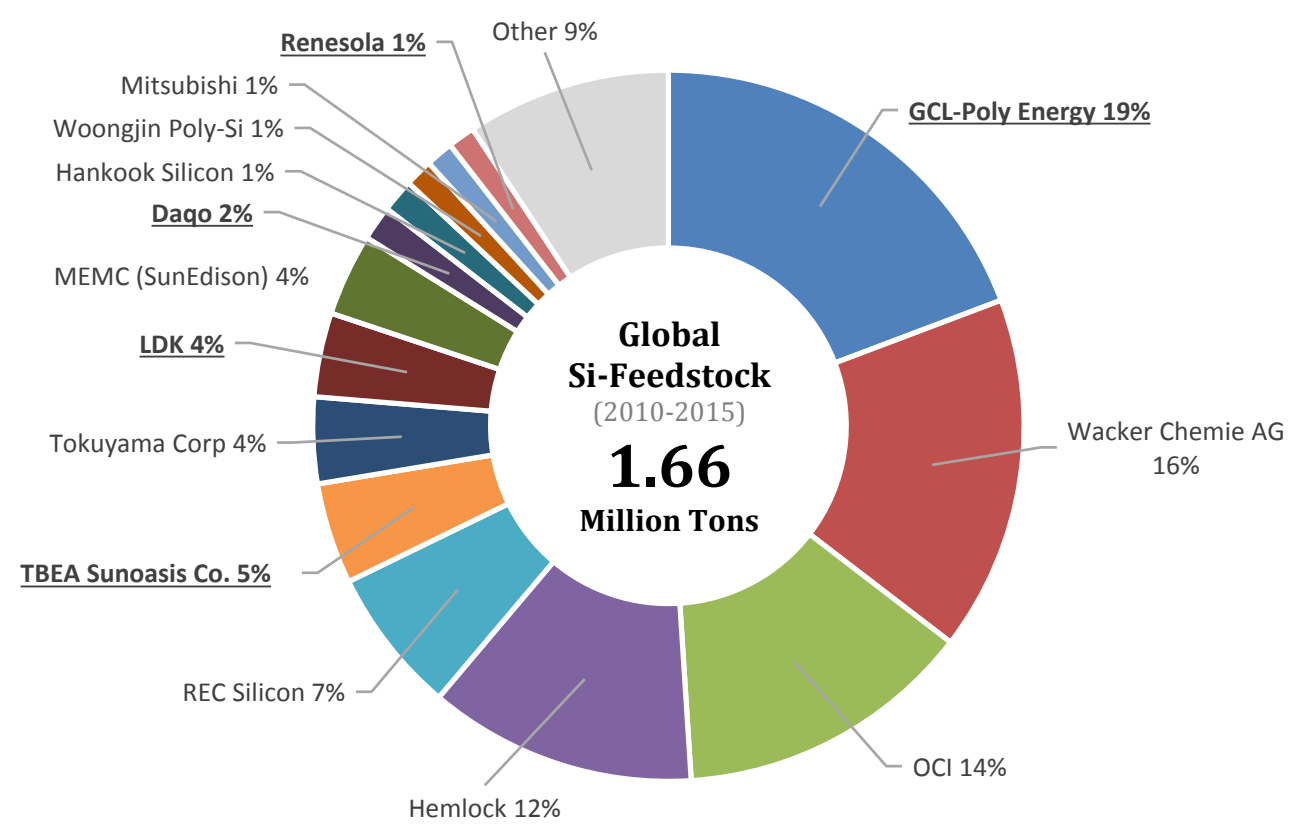

b. Global PV Cell Production

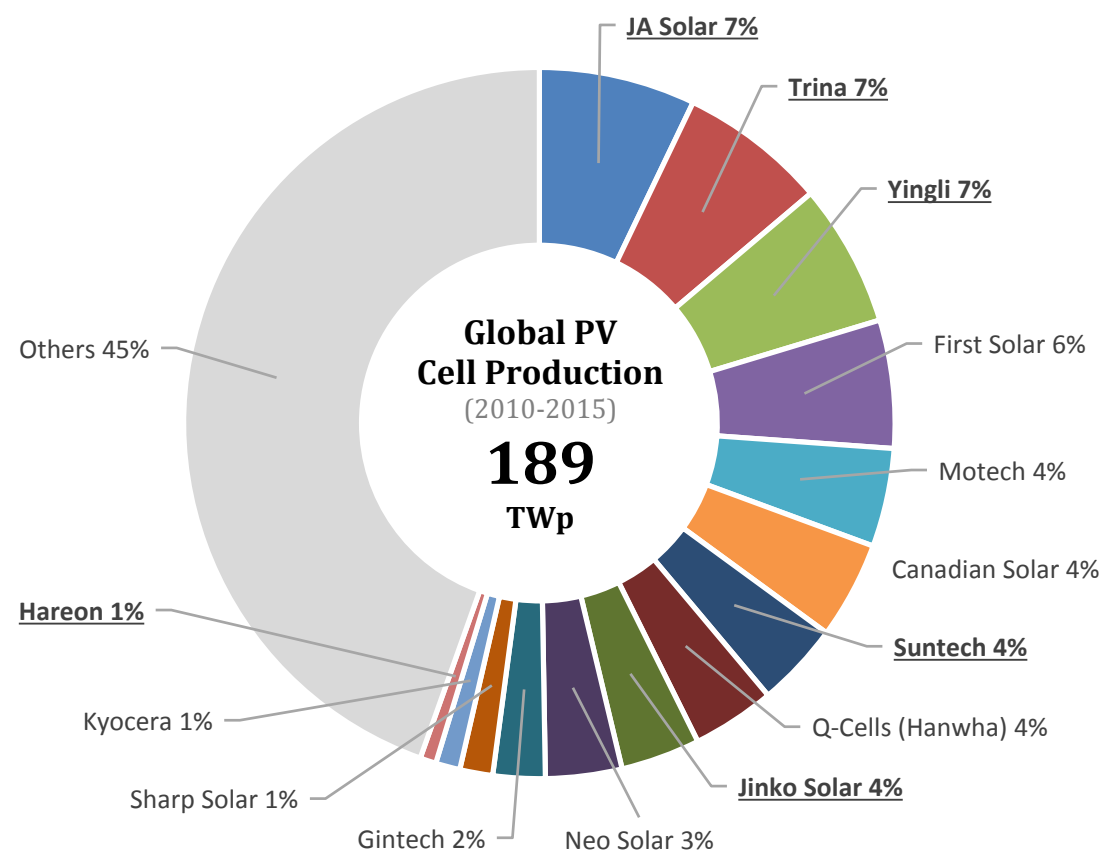

Author's own elaboration. Data compiled from the following sources: (Yu, et al., 2016; Roselund, 2016; Mints, 2014; Brown, et al., 2015; Shubbak, 2017b)

\subsubsection{Inventive Activities (Technological Profiles)}

To have a deeper insight into the actors driving the development of technological capabilities in the TIS of China, the patent analysis focuses next on the specialization profiles of the top 5\% transnational patent applicants during 1995-2014 (figure 3). The 
resulting 25 organisations directly accumulate $32 \%$ of the total Chinese transnational patents in PV technologies. Interestingly, 3 Chinese universities and 8 foreigner companies are found among these organisations. Figure 3 shows the patenting stocks of those top 25 applicants along with their technological profiles in the main PV groups. Similar to the overall trend within the Chinese transnational patent landscape in PV, the leading organisations are mostly specialized in cells and panels with only three exceptions. These are the State Grid Corp China, the American multinational enterprise General Electric, and the Chinese company Shanghai Convertergy, where high specialization in electronics is noticed.

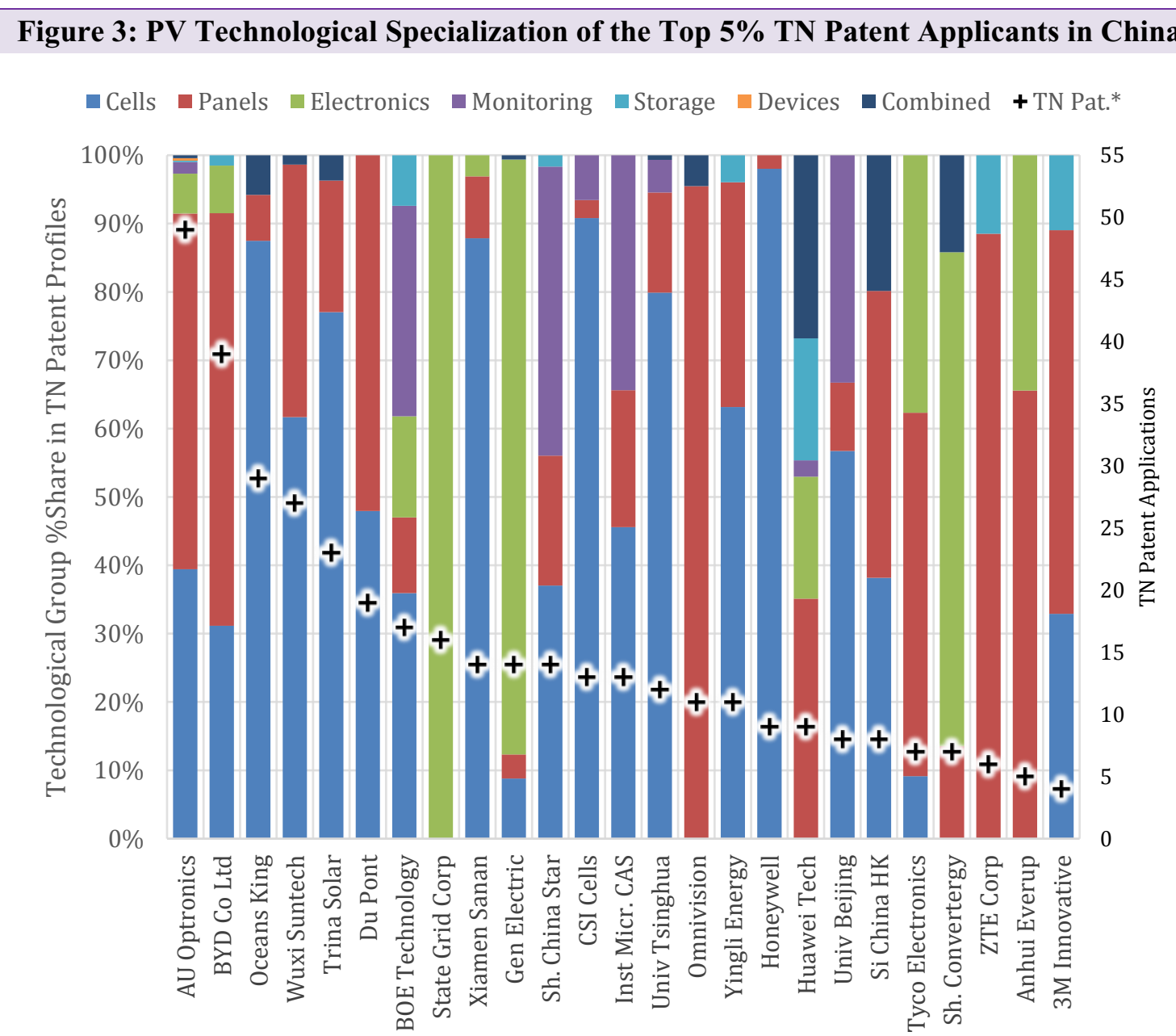

Actors in this figure are accountable for $32 \%$ of the total Chinese transnational patents in PV sector. * figures are shown in secondary axis. Data source: PATSTAT 2015b. Authors' own elaboration.

Going deeper to the next level of analysis, the technological profiles of the leading actors within the main three PV groups are considered. Within each field of solar cells, panels, and electronics, the top 10 patent assignees are listed against their patent shares in technological subgroups (figure 4). As shown in figure 4a, the specialization of solar cell innovators is highly focused in c-Si cells and elements. On the other hand, encapsulation and supporting structures form the specialization fields for solar panel innovators, while feeding converter circuits are on focus of electronics innovators. All applicants that appear in the top-10 innovator lists (figure 4) are considered for the research sample. 
Figure 4: Technological profiles of the top $10 \mathrm{PV}$ patent assignees in China during 1995-2014.

Heatmap representation of transnational patent applications in PV Cells, Panels and Electronics
$\begin{array}{lllllllll}0 & 2 & 4 & 6 & 8 & 10 & 12 & 14\end{array}$
Patent Applications
Heatmap Colour

(a) Solar Cell Technologies

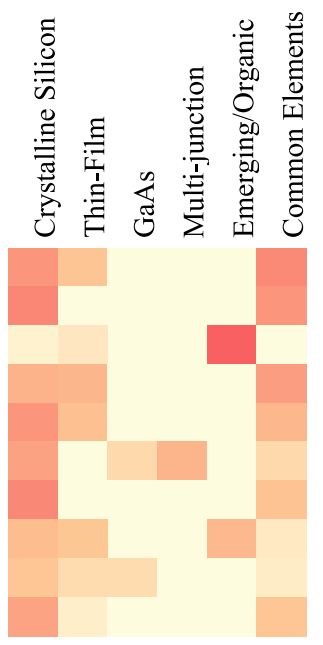

AU Optronics Corp

$\%$ in Cells

Changzhou Trina Solar Energy

$39 \%$

Oceans King Lighting Science

$79 \%$

$87 \%$

BYD Co Ltd

$40 \%$

Wuxi Suntech Power Co Ltd

$55 \%$

Xiamen Sanan Optoelectronics Technology Co Ltd

$84 \%$

CSI Cells Co Ltd

$91 \%$

Honeywell Int Inc

$94 \%$

University Tsinghua

$80 \%$

Yingli Energy China Company Ltd

$82 \%$

\section{(b) Solar Panel Technologies}

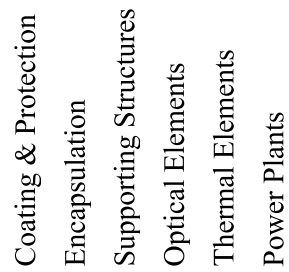

AU Optronics Corp
Byd Co Ltd

$\%$ in Panels

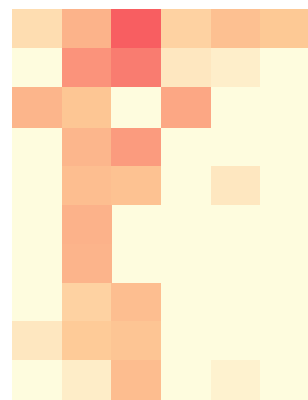

$54 \%$

Omnivision International Holding Ltd $\quad 95 \%$

Wuxi Suntech Power Co Ltd $\quad 44 \%$

Du Pont $\quad 53 \%$

Tyco Electronics Shanghai Co $\quad 65 \%$

Sandisk Information Technology Shanghai Co Ltd $\quad 99 \%$

ZTE Corp $\quad 81 \%$

Changzhou Trina Solar Energy $\quad 16 \%$

Anhui Everup Green Energy Co Ltd $\quad 71 \%$

(c) Electronic Technologies

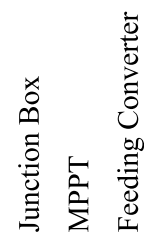

State Grid Corp China

$\%$ in Electronics

Gen Electric

$100 \%$

China Electric Power Res Inst

$77 \%$

$83 \%$

$100 \%$

Rongxin Power Electronic Co

$75 \%$

Shanghai Convertergy Energy Technology Co Ltd

$7 \%$

$\begin{array}{lr}\text { Boe Technology Group Co Ltd } & 21 \% \\ \text { State Grid Electric Power Res } & 100 \%\end{array}$

$\begin{array}{lr}\text { Siemens AG } & 83 \%\end{array}$

Huawei Tech Co Ltd $\quad 18 \%$ 


\subsection{Cluster Analysis}

Table 2 contains the descriptive statistics and the correlations between variables for all observations in the sample.

Table 2: Descriptive Statistics and Correlation Matrix

\begin{tabular}{|c|c|c|c|c|c|c|c|c|c|}
\hline & Variable $^{*}$ & Mean & Std. Dev. & Min & Max & 1 & 2 & 3 & 4 \\
\hline 1 & Pat & 11.27 & 10.80 & 0 & 49 & 1.000 & & & \\
\hline 2 & Fwd_Citn & 0.45 & 0.40 & 0 & 1.83 & 0.378 & 1.000 & & \\
\hline 3 & High_tech & 0.35 & 0.35 & 0 & 1 & 0.019 & 0.173 & 1.000 & \\
\hline 4 & Div & 0.29 & 0.47 & -1 & 0.86 & 0.405 & 0.412 & 0.064 & 1.000 \\
\hline 5 & Deg & 21.65 & 24.06 & -1 & 92 & 0.792 & 0.398 & 0.225 & 0.221 \\
\hline 6 & Btwn_cn & 462.62 & 1210.72 & -1 & 6717 & 0.248 & 0.181 & 0.137 & 0.072 \\
\hline 7 & Clust_coef & 0.27 & 0.51 & -1 & 1 & 0.022 & 0.104 & 0.273 & 0.579 \\
\hline 8 & Com_size & 33.49 & 39.59 & 0 & 134 & 0.280 & 0.180 & 0.292 & 0.207 \\
\hline 9 & Frgn_coll & 0.11 & 0.19 & 0 & 1 & -0.013 & 0.258 & -0.088 & 0.052 \\
\hline 10 & Turnover ${ }^{* *}$ & 13.50 & 25.80 & 0.003 & 117 & 0.009 & 0.349 & 0.457 & 0.099 \\
\hline 11 & Employees & 70,629 & 166,380 & 50 & 927,839 & 0.130 & 0.329 & 0.473 & -0.019 \\
\hline & Age & 41.05 & 44.71 & 3 & 168 & -0.100 & 0.313 & 0.230 & 0.128 \\
\hline & & 5 & 6 & 7 & 8 & 9 & 10 & 11 & 12 \\
\hline 5 & Deg & 1.000 & & & & & & & \\
\hline 6 & Btwn_cn & 0.500 & 1.000 & & & & & & \\
\hline 7 & Clust_coef & 0.041 & -0.064 & 1.000 & & & & & \\
\hline 8 & Com_size & 0.522 & 0.628 & 0.240 & 1.000 & & & & \\
\hline 9 & Frgn_coll & -0.049 & 0.050 & 0.112 & 0.084 & 1.000 & & & \\
\hline 10 & Turnover & 0.002 & -0.030 & -0.002 & -0.007 & 0.146 & 1.000 & & \\
\hline & Employees & 0.232 & 0.160 & -0.051 & 0.192 & -0.023 & 0.586 & 1.000 & \\
\hline 12 & Age & -0.126 & 0.143 & 0.132 & 0.043 & 0.246 & 0.600 & 0.207 & 1.000 \\
\hline
\end{tabular}

*. Number of observations $\mathrm{N}=37$.

**. Turnover values are given in billion US dollars, its $\mathrm{N}=36$.

Note: Variables are defined in table 1.

\subsubsection{Patterns of Innovation Capability}

Considering the quantity, quality and diversity of patenting activities as clustering variables for innovation capability, six clusters were identified. Figure 5 shows the normalized variables for each actor along with the distribution of actors into the resulting clusters.

To check the effectiveness of the analysis in classifying actors according to their innovative performance, Analysis of variance (ANOVA) is used. Furthermore, Tukey HSD post hoc test is subsequently conducted to understand the characteristics of each cluster. Table 3 contains the statistical results of ANOVA analysis and Tukey test for innovation capability clusters (INNO). 


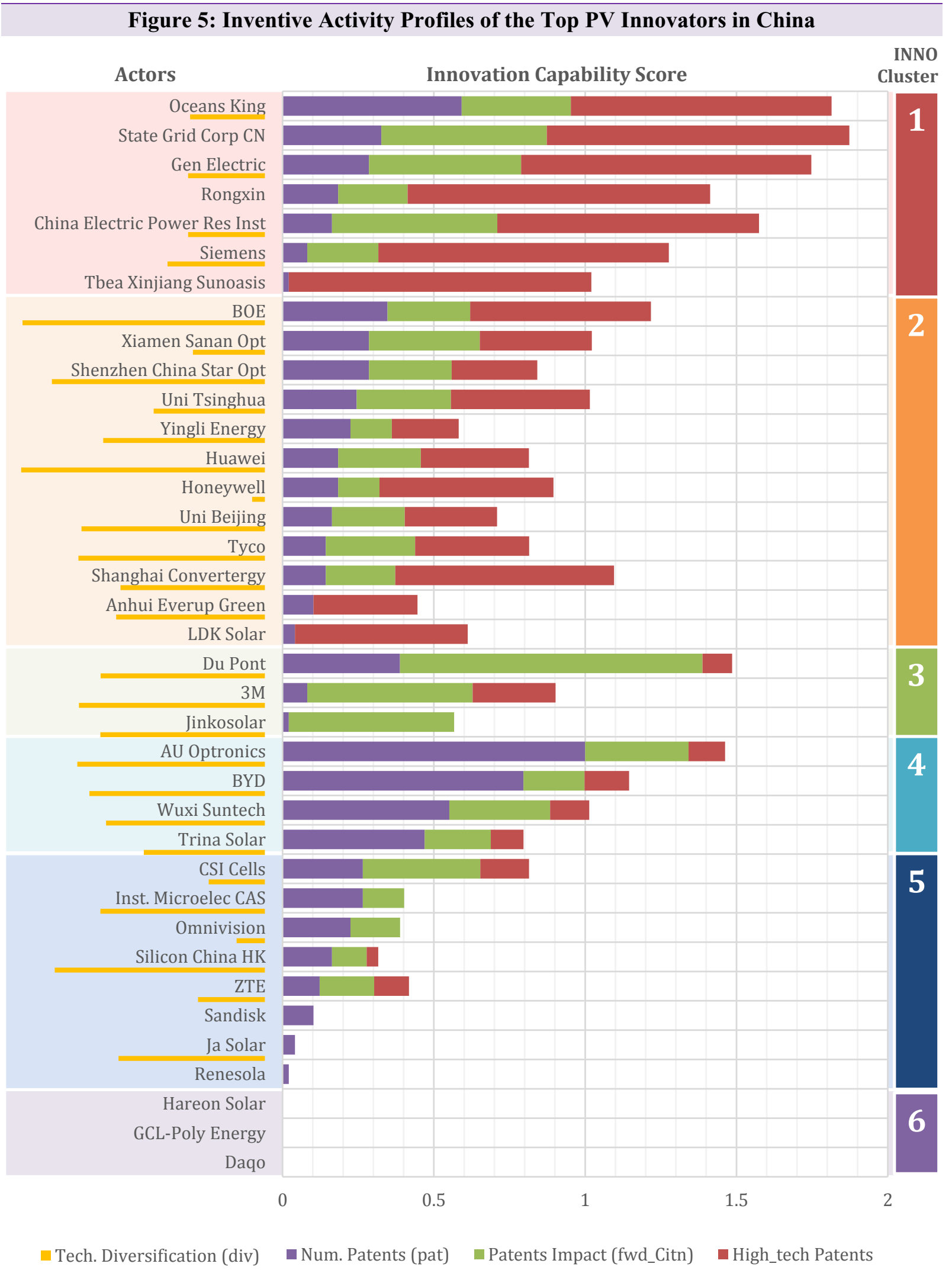

Authors' own elaboration, Data Source: PATSTAT 2015 
Table 3: ANOVA and Tukey HSD Analysis for Innovation Capability Clusters

\begin{tabular}{|c|c|c|c|c|c|c|}
\hline \multicolumn{7}{|c|}{ ANOVA Analysis for Innovation Capability Clusters } \\
\hline & & Sum of Squares & df & Mean Square & $\mathbf{F}$ & Sig. \\
\hline \multirow[t]{3}{*}{ pat } & Between Groups & 2727.791 & 5 & 545.558 & 11.478 & $0.000^{* *}$ \\
\hline & Within Groups & 1473.506 & 31 & 47.532 & & \\
\hline & Total & 4201.297 & 36 & & & \\
\hline \multirow[t]{3}{*}{ fwd_citn } & Between Groups & 3.355 & 5 & 0.671 & 9.146 & $0.000^{* *}$ \\
\hline & Within Groups & 2.274 & 31 & 0.073 & & \\
\hline & Total & 5.630 & 36 & & & \\
\hline \multirow[t]{3}{*}{$\operatorname{div}$} & Between Groups & 6.289 & 5 & 1.258 & 23.612 & $0.000^{* *}$ \\
\hline & Within Groups & 1.651 & 31 & 0.053 & & \\
\hline & Total & 7.940 & 36 & & & \\
\hline \multirow[t]{3}{*}{ high_tech } & Between Groups & 4.089 & 5 & 0.818 & 73.321 & $0.000^{* *}$ \\
\hline & Within Groups & 0.346 & 31 & 0.011 & & \\
\hline & Total & 4.435 & 36 & & & \\
\hline
\end{tabular}

\begin{tabular}{|c|c|c|c|c|c|c|c|}
\hline \multicolumn{8}{|c|}{ Post Hoc Test: Multiple Comparisons (Tukey HSD) } \\
\hline \multirow{2}{*}{$\begin{array}{l}\text { Dependent } \\
\text { Variable }\end{array}$} & \multirow{2}{*}{$\begin{array}{l}\text { INNO } \\
\text { (I) }\end{array}$} & \multirow{2}{*}{$\begin{array}{c}\text { INNO } \\
(\mathbf{J})\end{array}$} & \multirow{2}{*}{$\begin{array}{c}\text { Mean Diff. } \\
\text { (I-J) }\end{array}$} & \multirow{2}{*}{ Std. Error } & \multirow{2}{*}{ Sig. } & \multicolumn{2}{|c|}{ 95\% Confidence Interval } \\
\hline & & & & & & Lower Bound & Upper Bound \\
\hline \multirow[t]{9}{*}{ high_tech } & \multirow[t]{5}{*}{1} & 2 & $.518^{* *}$ & 0.050 & 0.000 & 0.365 & 0.670 \\
\hline & & 3 & $.825^{* *}$ & 0.073 & 0.000 & 0.604 & 1.047 \\
\hline & & 4 & $.823^{* *}$ & 0.066 & 0.000 & 0.622 & 1.024 \\
\hline & & 5 & $.910^{* *}$ & 0.055 & 0.000 & 0.744 & 1.076 \\
\hline & & 6 & $.949^{* *}$ & 0.073 & 0.000 & 0.728 & 1.171 \\
\hline & \multirow[t]{4}{*}{2} & 3 & $.308^{* *}$ & 0.068 & 0.001 & 0.101 & 0.515 \\
\hline & & 4 & $.306^{* *}$ & 0.061 & 0.000 & 0.121 & 0.491 \\
\hline & & 5 & $.393^{* *}$ & 0.048 & 0.000 & 0.246 & 0.539 \\
\hline & & 6 & $.432^{* *}$ & 0.068 & 0.000 & 0.225 & 0.639 \\
\hline \multirow[t]{5}{*}{ fwd_citn } & \multirow[t]{5}{*}{3} & 1 & $.644^{*}$ & 0.187 & 0.019 & 0.076 & 1.211 \\
\hline & & 2 & $.890^{* *}$ & 0.175 & 0.000 & 0.359 & 1.421 \\
\hline & & 4 & $.775^{* *}$ & 0.207 & 0.009 & 0.148 & 1.403 \\
\hline & & 5 & $1.052^{* *}$ & 0.183 & 0.000 & 0.495 & 1.608 \\
\hline & & 6 & $1.277^{* *}$ & 0.221 & 0.000 & 0.605 & 1.948 \\
\hline \multirow[t]{5}{*}{ pat } & \multirow[t]{5}{*}{4} & 1 & $22.929^{* *}$ & 4.321 & 0.000 & 9.810 & 36.040 \\
\hline & & 2 & $24.917^{* *}$ & 3.980 & 0.000 & 12.840 & 37.000 \\
\hline & & 3 & $26.500^{* *}$ & 5.266 & 0.000 & 10.520 & 42.480 \\
\hline & & 5 & $27.125^{* *}$ & 4.222 & 0.000 & 14.310 & 39.940 \\
\hline & & 6 & $34.500^{* *}$ & 5.266 & 0.000 & 18.520 & 50.480 \\
\hline \multirow[t]{6}{*}{ div } & 1 & 6 & $1.165^{* *}$ & 0.159 & 0.000 & 0.681 & 1.648 \\
\hline & \multirow[t]{2}{*}{2} & 1 & $.343^{*}$ & 0.110 & 0.041 & 0.010 & 0.676 \\
\hline & & 6 & $1.508^{* *}$ & 0.149 & 0.000 & 1.056 & 1.960 \\
\hline & 3 & 6 & $1.608^{* *}$ & 0.188 & 0.000 & 1.036 & 2.180 \\
\hline & 4 & 6 & $1.570^{* *}$ & 0.176 & 0.000 & 1.035 & 2.105 \\
\hline & 5 & 6 & $1.298^{* *}$ & 0.156 & 0.000 & 0.824 & 1.772 \\
\hline
\end{tabular}

Only positive significant mean differences are shown in this table. Definitions of variables are stated in table 1.

*. The mean difference is significant at the 0.05 level.

**. The mean difference is significant at the 0.01 level. 
The results show that for all clustering variables, there was a statistically significant difference between INNO clusters as determined by one-way ANOVA at the $p<0.001$ level. The post hoc comparisons, using Tukey HSD test, revealed that high-tech innovations were significantly higher in the first cluster INNO1 compared to all other clusters. INNO2 had also significantly greater high-tech innovations than those of INNO3, 4, 5, and 6 . On the other hand, the cluster INNO3 showed statistically significant advantage over all other clusters in forward-citation score. The quantity of innovative activities (number of patent filings) was significantly higher in INNO4 compared to the others. Finally, in terms of technological diversification, INNO6 was significantly lower than all other clusters. INNO1 also had significantly lower diversification than INNO2.

Taken together, these results give better insight into the differences between clusters:

1. INNO1: comprises the actors with high-tech speciality.

2. INNO2: actors have higher diversity within medium technological sophistication.

Although the remaining clusters are specialized in low-tech, each one of them has its defining characteristic:

3. INNO3: actors have patents with high impact (i.e. receiving more forward citations).

4. INNO4: actors have high quantity and technological diversity of patent filings.

5. INNO5: innovations are low in quantity and quality.

6. INNO6: firms did not file any transnational patents in the period of consideration.

\subsubsection{Patterns of Network Embeddedness}

The second analytical dimension is built upon network analysis of collaboration in patents. Figure 6 shows a subgraph of co-patenting network of PV in China. It contains the components to which the identified actors of the sample belong. This subgraph represents $35 \%$ of the complete network in terms of nodes and $51 \%$ in terms of edges. The colour of nodes represents the country where applicants are located.

In this stage a second cluster analysis is conducted, but this time based on network embeddedness variables. The resulting clusters are labelled with NET throughout this paper. Furthermore, node labels in figure 6 are coloured based on their NET clusters. Five NET clusters were identified.

Similar to the procedure done for INNO clusters (section 4.2.1), one-way ANOVA and Tukey HSD test is conducted for NET clusters (table 4). Again, the results show that for all clustering variables, there was a statistically significant difference between NET clusters at the $p<0.001$ level. Tukey HSD test revealed significant advantage for the first cluster NET1 in collaboration with foreigners. On the other hand, actors within NET2 had significantly higher component size, degree, and betweenness centrality than other clusters. Network clustering coefficients for actors in NET3 were significantly larger than those of other NET clusters. 


\section{Figure 6: Co-Patenting Network of the Top PV Innovators in China}

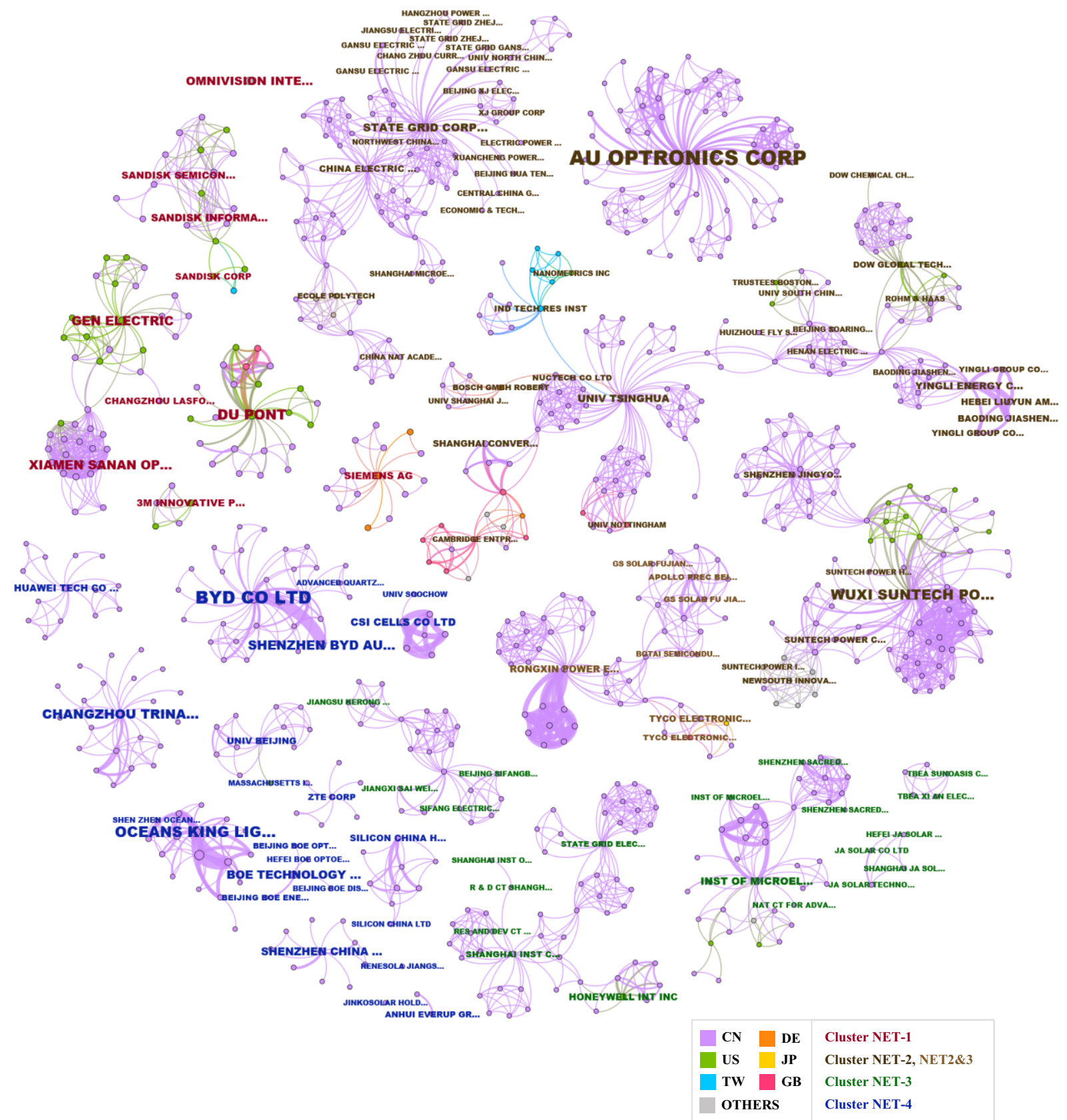

Subgraph of the co-patenting network of Chinese transnational patents over 1995-2014. 35\% of nodes and $51 \%$ of edges are visible. Data sources: PATSTAT 2015b; (Dominguez Lacasa \& Shubbak, 2018). Authors' own elaboration.

Taken together, these results show:

1. NET1: contains actors with high global integration.

2. NET2: actors have high embeddedness in the collaboration network as shown by their central positions in relatively large components.

3. NET3: fulfils the requirements of small-world networks, given the relatively low degree and high clustering coefficients of its actors.

4. NET4: contains actors with low network embeddedness.

5. NET5: contains firms that did not file any transnational patents. 
Table 4: ANOVA and Tukey HSD Analysis for Network Embeddedness Clusters

\begin{tabular}{|c|c|c|c|c|c|c|}
\hline & & Sum of Squares & df & Mean Square & $\mathbf{F}$ & Sig. \\
\hline \multirow{3}{*}{$\operatorname{deg}$} & Between Groups & 11440.301 & 4 & 2860.075 & 9.740 & $0.000^{*}$ \\
\hline & Within Groups & 9396.131 & 32 & 293.629 & & \\
\hline & Total & 20836.432 & 36 & & & \\
\hline \multirow{3}{*}{ btwn_centr } & Between Groups & 22669354.315 & 4 & 5667338.579 & 6.025 & $0.001^{*}$ \\
\hline & Within Groups & 30100986.107 & 32 & 940655.816 & & \\
\hline & Total & 52770340.422 & 36 & & & \\
\hline \multirow{3}{*}{ clust_coef } & Between Groups & 7.228 & 4 & 1.807 & 26.729 & $0.000^{*}$ \\
\hline & Within Groups & 2.163 & 32 & 0.068 & & \\
\hline & Total & 9.392 & 36 & & & \\
\hline \multirow{3}{*}{ com_Size } & Between Groups & 43785.029 & 4 & 10946.257 & 27.703 & $0.000^{*}$ \\
\hline & Within Groups & 12644.214 & 32 & 395.132 & & \\
\hline & Total & 56429.243 & 36 & & & \\
\hline \multirow{3}{*}{ frgn_coll } & Between Groups & 0.863 & 4 & 0.216 & 13.921 & $0.000^{*}$ \\
\hline & Within Groups & 0.496 & 32 & 0.016 & & \\
\hline & Total & 1.360 & 36 & & & \\
\hline
\end{tabular}

\begin{tabular}{|c|c|c|c|c|c|c|c|}
\hline \multirow{2}{*}{$\begin{array}{l}\text { Dependent } \\
\text { Variable }\end{array}$} & \multirow{2}{*}{$\begin{array}{c}\text { NET } \\
\text { (I) }\end{array}$} & \multirow{2}{*}{$\begin{array}{c}\text { NET } \\
\text { (J) }\end{array}$} & \multirow{2}{*}{$\begin{array}{l}\text { Mean Diff. } \\
\text { (I-J) }\end{array}$} & \multirow{2}{*}{$\begin{array}{l}\text { Std. } \\
\text { Error }\end{array}$} & \multirow{2}{*}{ Sig. } & \multicolumn{2}{|c|}{ 95\% Confidence Interval } \\
\hline & & & & & & Lower Bound & Upper Bound \\
\hline \multirow[t]{4}{*}{ frgn_coll } & \multirow[t]{4}{*}{1} & 2 & $.307^{* *}$ & 0.064 & 0.000 & 0.120 & 0.493 \\
\hline & & 3 & $.390^{* *}$ & 0.069 & 0.000 & 0.189 & 0.590 \\
\hline & & 4 & $.407^{* *}$ & 0.058 & 0.000 & 0.238 & 0.575 \\
\hline & & 5 & $.413^{* *}$ & 0.086 & 0.000 & 0.165 & 0.661 \\
\hline \multirow[t]{4}{*}{ com_Size } & \multirow[t]{4}{*}{2} & 1 & $76.411^{* *}$ & 10.288 & 0.000 & 46.685 & 106.136 \\
\hline & & 3 & $67.292^{* *}$ & 10.735 & 0.000 & 36.273 & 98.310 \\
\hline & & 4 & $86.510^{* *}$ & 8.932 & 0.000 & 60.701 & 112.319 \\
\hline & & 5 & $97.125^{* *}$ & 13.457 & 0.000 & 58.241 & 136.009 \\
\hline \multirow[t]{4}{*}{$\operatorname{deg}$} & \multirow[t]{4}{*}{2} & 1 & $36.375^{* *}$ & 8.869 & 0.002 & 10.750 & 62.000 \\
\hline & & 3 & $47.042^{* *}$ & 9.254 & 0.000 & 20.302 & 73.781 \\
\hline & & 4 & $36.452^{* *}$ & 7.700 & 0.000 & 14.203 & 58.700 \\
\hline & & 5 & $54.375^{* *}$ & 11.601 & 0.000 & 20.856 & 87.894 \\
\hline \multirow[t]{4}{*}{ btwn_centr } & \multirow[t]{4}{*}{2} & 1 & $1857.759^{* *}$ & 501.958 & 0.007 & 407.405 & 3308.112 \\
\hline & & 3 & $1924.116^{* *}$ & 523.792 & 0.007 & 410.674 & 3437.557 \\
\hline & & 4 & $1900.222^{* *}$ & 435.821 & 0.001 & 640.963 & 3159.482 \\
\hline & & 5 & $1953.116^{*}$ & 656.608 & 0.041 & 55.917 & 3850.315 \\
\hline \multirow[t]{7}{*}{ clust_coef } & 1 & 5 & $1.426^{* *}$ & 0.179 & 0.000 & 0.908 & 1.945 \\
\hline & 2 & 5 & $1.296^{* *}$ & 0.176 & 0.000 & 0.787 & 1.805 \\
\hline & \multirow[t]{4}{*}{3} & 1 & $.439^{*}$ & 0.145 & 0.036 & 0.021 & 0.857 \\
\hline & & 2 & $.569^{* *}$ & 0.140 & 0.003 & 0.163 & 0.975 \\
\hline & & 4 & $.678^{* *}$ & 0.128 & 0.000 & 0.307 & 1.049 \\
\hline & & 5 & $1.865^{* *}$ & 0.184 & 0.000 & 1.334 & 2.396 \\
\hline & 4 & 5 & $1.187^{* *}$ & 0.167 & 0.000 & 0.706 & 1.668 \\
\hline
\end{tabular}

Only positive significant mean differences are shown in this table. Definitions of variables are stated in table 1.

*. The mean difference is significant at the 0.05 level.

**. The mean difference is significant at the 0.01 level. 


\subsection{Concurrency Analysis}

The analysis explained in section 4.2 resulted in clearly discernible clusters for both innovation capability and network embeddedness. However, towards achieving the aim of this research of understanding the confluence of both dimensions on the economic performance, a concurrency matrix of their cross relations is created (table 5).

Having the NET clusters as rows and the INNO clusters as columns ${ }^{5}$, the concurrency matrix provides the exact positioning of actors in this two-dimensional space. As shown in table 5 , actors can be found in 16 out of the 30 possible combinations in the matrix.

Table 5: Concurrency Matrix - Mapping of PV Innovators in China

\begin{tabular}{|c|c|c|c|c|c|c|c|c|}
\hline & & & INNO-6 & INNO-5 & INNO-4 & INNO-3 & INNO-2 & INNO-1 \\
\hline 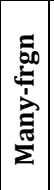 & 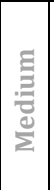 & 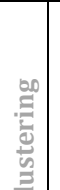 & & $\begin{array}{l}\text { Sandisk } \\
\text { Omnivision }\end{array}$ & & $\begin{array}{l}\text { Du-Pont } \\
3 \mathrm{M}\end{array}$ & X.Sanan-Opt & $\begin{array}{l}\text { Siemens } \\
\text { Gen Elect }\end{array}$ \\
\hline 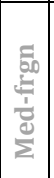 & 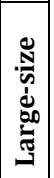 & 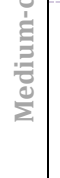 & & & $\begin{array}{l}\text { Wuxi-Suntech } \\
\text { AU-Optronics }\end{array}$ & & $\begin{array}{l}\text { Yingli } \\
\text { S.Convertergy } \\
\text { Uni-Tsinghua }\end{array}$ & $\begin{array}{l}\text { State Grid CC } \\
\text { CEPR } \\
\text { Rongxin }\end{array}$ \\
\hline$\frac{0}{0}$ & 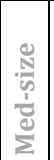 & 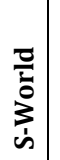 & & $\begin{array}{l}\text { Inst.Micr-CAS } \\
\text { Ja-Solar }\end{array}$ & & & $\begin{array}{l}\text { Honeywell } \\
\text { Tyco } \\
\text { LDK-Solar }\end{array}$ & TX-Sunoasis \\
\hline $\mid$ & 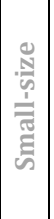 & 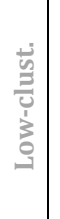 & & $\begin{array}{l}\text { ZTE } \\
\text { CSI-Cells } \\
\text { Si-China-HK } \\
\text { Renesola }\end{array}$ & $\begin{array}{l}\text { BYD } \\
\text { Trina-Solar }\end{array}$ & Jinkosolar & $\begin{array}{l}\text { BOE } \\
\text { S.China-Star } \\
\text { Huawei } \\
\text { Uni-Beijing } \\
\text { Anhui-Everup }\end{array}$ & Oceans-King \\
\hline & 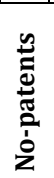 & & $\begin{array}{l}\text { GCL-Poly } \\
\text { Daqo } \\
\text { Hareon }\end{array}$ & & & & & \\
\hline & & & & Few-patents & Many-patents & Few-patents & Medium & 1-patents \\
\hline & & & No-patents & Low-impact & Med-impact & High-impact & Mediun & a-impact \\
\hline & & & & & Low-tech & & Med-tech & High-tech \\
\hline
\end{tabular}

Besides its important use as illustrative tool per se for understanding the nature of actors' technological engagement, the introduced concurrency matrix provides a promising basis for classifying new actors within the system or even for inductively generalizing the classification into other technological fields and systems. Another important application of the matrix is to use it for testing the research hypotheses.

To investigate whether a significant relationship can be found between the identified patterns, concurrency interactions, and economic performance of actors, a two-way multivariate analysis of variance (MANOVA) is utilized having age, size, turnover, and productivity as dependent variables. Table 6 shows the results of Pillai's trace, Wilks' Lambda, Hotelling's trace, and Roy's largest root multivariate tests of the full factorial 
model of INNO and NET clusters. The results show significant relationships between INNO*NET interaction on the economic performance at the level of $\mathrm{p}<0.01$. This result confidently rejects the null hypothesis that the multivariate means of all groups are equal.

Table 6: Results of multivariate tests for INNO*NET full factorial model

\begin{tabular}{|c|c|c|c|c|c|c|}
\hline \multicolumn{7}{|c|}{ Multivariate Tests ${ }^{a}$} \\
\hline Effect & & Value & $\mathbf{F}$ & Hypothesis df & Error df & Sig. \\
\hline \multirow[t]{4}{*}{ Intercept } & Pillai's Trace & $0.936^{* *}$ & $61.766^{\mathrm{b}}$ & 4.000 & 17.000 & 0.000 \\
\hline & Wilks' Lambda & $0.064^{* *}$ & $61.766^{\mathrm{b}}$ & 4.000 & 17.000 & 0.000 \\
\hline & Hotelling's Trace & $14.533^{* *}$ & $61.766^{\mathrm{b}}$ & 4.000 & 17.000 & 0.000 \\
\hline & Roy's Largest Root & $14.533^{* *}$ & $61.766^{\mathrm{b}}$ & 4.000 & 17.000 & 0.000 \\
\hline \multirow[t]{4}{*}{ INNO } & Pillai's Trace & 0.946 & 1.549 & 16.000 & 80.000 & 0.103 \\
\hline & Wilks' Lambda & $0.260^{*}$ & 1.824 & 16.000 & 52.573 & 0.052 \\
\hline & Hotelling's Trace & $2.090^{* *}$ & 2.025 & 16.000 & 62.000 & 0.025 \\
\hline & Roy's Largest Root & $1.656^{* *}$ & $8.282^{\mathrm{c}}$ & 4.000 & 20.000 & 0.000 \\
\hline \multirow[t]{4}{*}{ NET } & Pillai's Trace & $1.151^{* *}$ & 2.955 & 12.000 & 57.000 & 0.003 \\
\hline & Wilks' Lambda & $0.190^{* *}$ & 3.290 & 12.000 & 45.269 & 0.002 \\
\hline & Hotelling's Trace & $2.558^{* *}$ & 3.340 & 12.000 & 47.000 & 0.001 \\
\hline & Roy's Largest Root & $1.585^{* *}$ & $7.528^{c}$ & 4.000 & 19.000 & 0.001 \\
\hline \multirow[t]{4}{*}{ INNO * NET } & Pillai's Trace & $1.768^{* *}$ & 2.263 & 28.000 & 80.000 & 0.002 \\
\hline & Wilks' Lambda & $0.046^{* *}$ & 3.006 & 28.000 & 62.717 & 0.000 \\
\hline & Hotelling's Trace & $6.709^{* *}$ & 3.714 & 28.000 & 62.000 & 0.000 \\
\hline & Roy's Largest Root & $4.640^{* *}$ & $13.257^{\mathrm{c}}$ & 7.000 & 20.000 & 0.000 \\
\hline $\begin{array}{l}\text { a. Design: Inter } \\
\text { c. The statistic } \\
\text { lower bound }\end{array}$ & $\begin{array}{l}\text { cept }+ \text { INNO + NET + } \\
\text { is an upper bound on F } \\
\text { on the significance leve }\end{array}$ & $\begin{array}{l}\text { * NET. } \\
\text { elds a }\end{array}$ & $\begin{array}{r}\text { b. Exac } \\
\text { *. Sign } \\
\text { **. Sign }\end{array}$ & $\begin{array}{l}\text { tic } \\
\text { at the } 0.1 \text { level } \\
\text { at the } 0.05 \text { leve }\end{array}$ & & \\
\hline
\end{tabular}

Inspecting the model for between-subject effects on each dependent variable, table A2 shows a significant effect of innovation-capability on actors' turnover, as well as significant relationships between network-embeddedness, age, turnover and productivity. Similar significant relationships were found between INNO*NET interaction with the dependent variables of age and economic performance. However, no significant effects were found for any of the model elements on firms' size (number of employees).

To clearly illustrate the results and test the research hypotheses, the identified patterns are combined based on their commonalities. This results in three innovation levels:

1. High-quality innovation level: combines the high-tech and high-impact innovation clusters, INNO1 and INNO3 respectively.

2. High-diversity innovation level: combines the diverse med-tech and high-quantity clusters, INNO2 and INNO4 respectively.

3. Low innovation level: combines the innovation clusters INNO5 and INNO6.

On a related front, three network patterns are defined as:

A. High centrality pattern: contains the highly embedded actors of the cluster NET2.

B. Small-world pattern: combines the globally integrated and highly clustered actors of NET1 and NET3 respectively.

C. Low embeddedness pattern: combines the network clusters NET4 and NET5. 
Figure 7 illustrates the detailed comparisons of dependent variables (estimated marginal means) across the innovation groups and network patterns.

\section{Figure 7: Age, Size, and Economic Performance across Concurrency-Matrix Clusters}

(a) Age of Actors

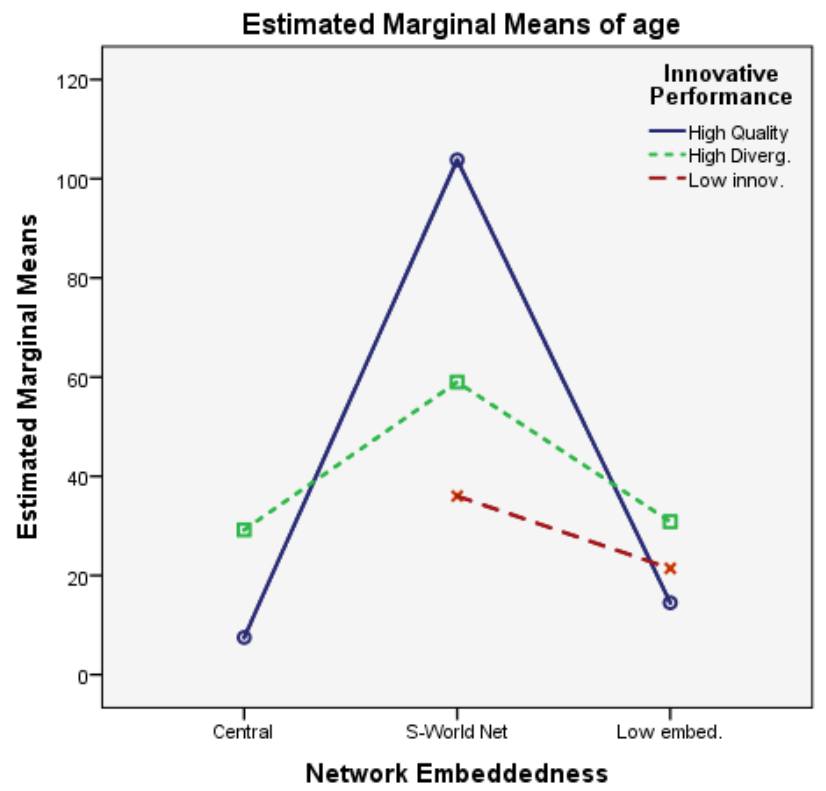

(c) Turnover of Actors (operating revenue)

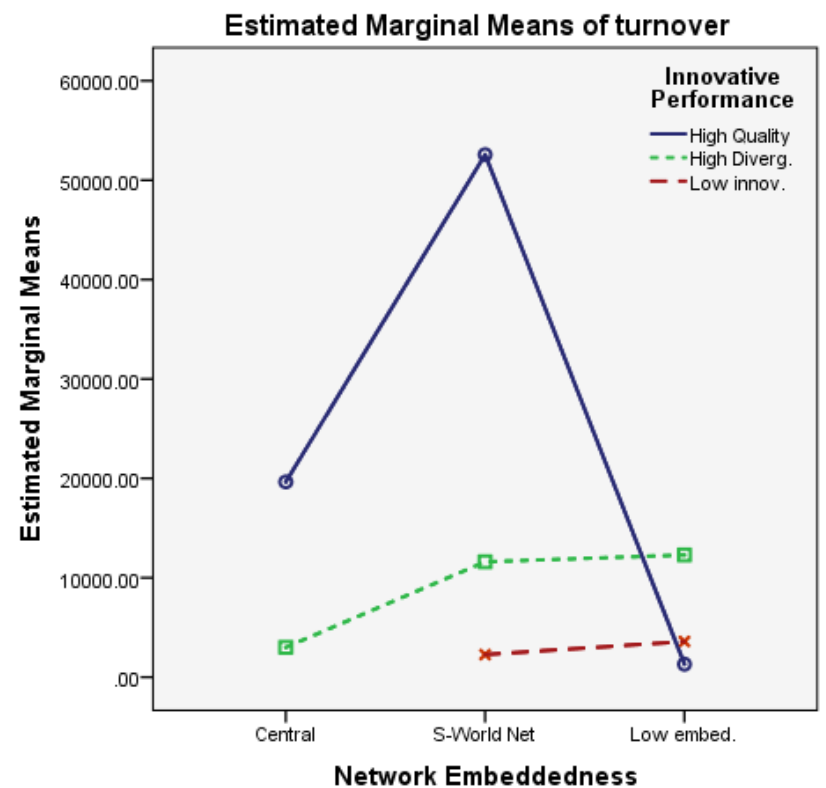

(b) Size of Actors (Number of Employees)

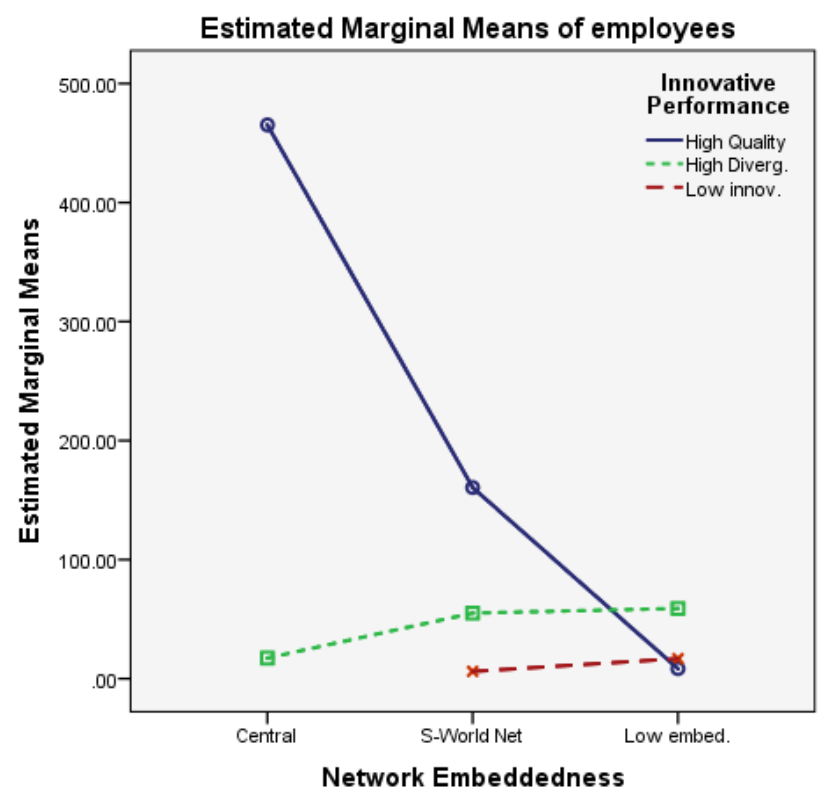

(d) Productivity of Actors

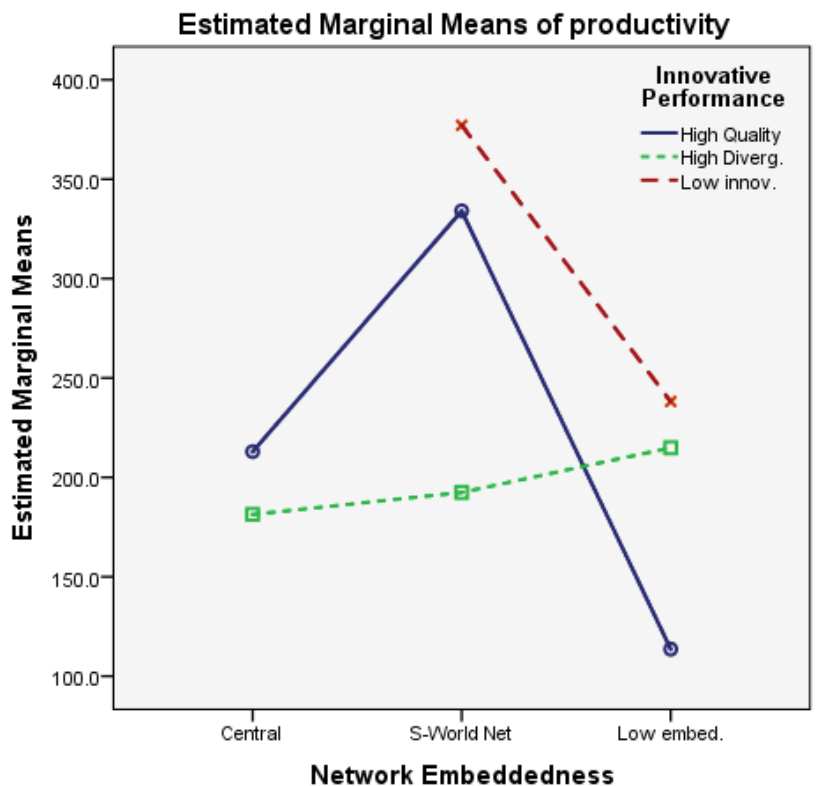

Authors' own elaboration.

\subsection{The complete image}

Putting everything together, figure 8 shows the full overview of the main actors within the Chinese innovation system of PV technology. The circular visualization shows actor profiles, clustering variables, resulting clusters, concurrency, and productivity (as an indicator of economic performance). 
The upper half of the circle represents INNO clusters, with heatmaps of their clustering variables, as well as a bar chart of economic productivity. The lower half of the visualization represents the NET clusters along with their clustering variables heatmap.

Actors are numbered as in table A1. The central area within the circular graph shows the concurrency relations between the two cluster sets. Finally, co-patenting links are shown in the lower left quarter of the figure. The figure helps better understanding of the results and viewing all the discussed aspects simultaneously.

\section{Figure 8: The Complete Image of PV Innovators in China}

Circular Visualization of Clustering, Concurrency, and Economic Performance

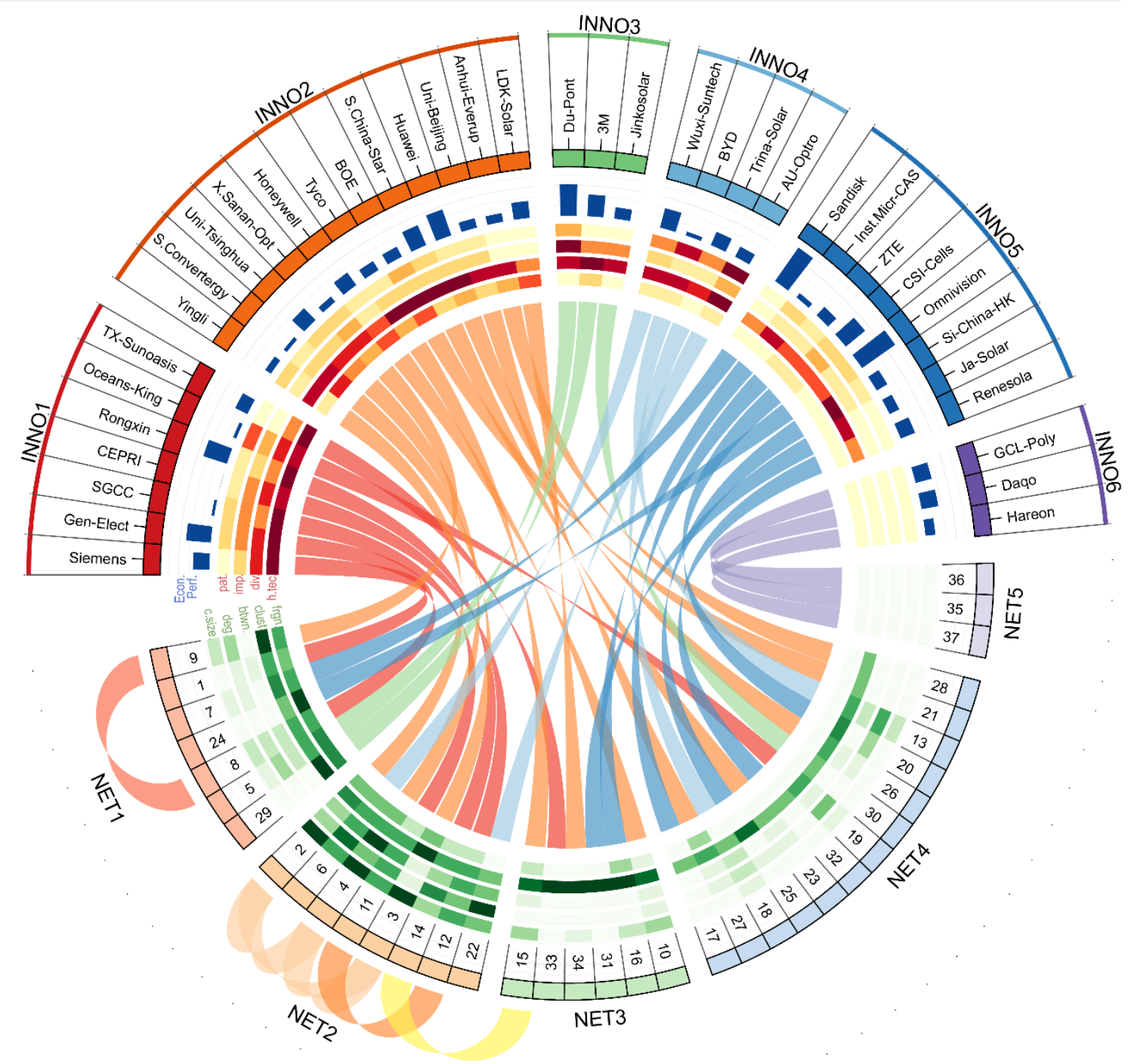

Author's own elaboration.

\section{DISCUSSION AND HYPOTHESES TESTING}

As the main aim of this paper is to disentangle the combined effects of innovationcapability and network-embeddedness on firms' performance, this section discusses the empirical results through testing the research hypotheses introduced in section 2. 
According to figure 7c, actors with high-quality innovations and actors with highdiversity have significantly higher turnover than those with low innovation capability. This result supports Hypothesis 1a, which stated that organizations with high innovationcapability are likely to achieve higher economic performance. This result confirms the large body of literature on the positive economic impact of innovation, such as (Adeyeye, et al., 2013; Andries \& Faems, 2013; Hashi \& Stojčić, 2013; Silva, et al., 2017).

Although the hypothesis 1a is strongly supported for turnover, a non-significant negative effect can be found for the second indicator of economic performance: productivity (figure 7d), where low innovative actors score higher productivity levels. While such finding sounds contradicted with (Cainelli, et al., 2006), it can be better explained by the fact that such low innovative firms are of smaller size and usually focus on matured technologies and manufacturing of the 'dominant-design', where mass production is more important than R\&D for a successful business. This highlights an additional difference between manufacturing and service sectors. However, given this result of a higher productivity scored by less innovative firms, does it mean that the high R\&D expenses yields a negative outcome on the overall financial performance of firms within the manufacturing sector? To answer this question a more careful consideration of the economic system is needed. Despite the communist political system of China, its economic system is totally capitalist. Which means that business success is more accurately measured by firms' net profits than productivity. As shown in table A1, the large firms in the Chinese PV sector have on average much larger revenues and profits than small and medium enterprises despite their lower productivity. For such large firms, innovation plays a key role in maintaining their market leadership.

Hypothesis 1b suggested a positive relationship between firm's age and innovation capability. The results shown in figure 7a support this hypothesis, as firms with highquality innovations or high-diversity are relatively older than low-innovation firms. This result further supports the theoretical rationale introduced in section 2.1.

Figure $7 \mathrm{~b}$ shows positive relationships between firm size, on the one hand, and innovation capability and network embeddedness, on the other. This sound compatible with the literature reviewed in section 2, such as (Wang, et al., 2018), as well as with the Hypotheses 1c and 2c, which stated that larger firms tend to have higher innovation capability and are more embedded in knowledge networks. However, due to the nonsignificant MANOVA for the dependent variable 'employees', we cannot confidently accept hypotheses $1 \mathrm{c}$ and $2 \mathrm{c}$, nor reject them.

Hypothesis 1d suggested a higher importance of innovation quality than quantity in influencing economic performance. The results shown in figure 7 support this hypothesis (only in highly embedded networks), where actors with high-quality innovations achieved higher turnover and productivity levels than those with high-diversity and quantity. This result stresses the significant role of influential process innovations as well as radical product innovations for manufacturing firms to achieve and maintain high economic performance within the technology-based sector of solar PV. 
Regarding network embeddedness, figures $7 \mathrm{c}$ and $7 \mathrm{~d}$ show higher economic outcomes for small-world and high-centrality patterns only when innovation quality is high. However, network embeddedness is negatively related with economic performance in the other innovation levels. This yields a partial support of Hypothesis 2a, which stated that the network embeddedness of an organization is positively related to its economic performance. Additionally, since actors in small-world networks are relatively older than low-embedded firms (figure 7a), Hypothesis 2b (stating: older organizations are more embedded in networks) is supported. These results further confirm the theoretical rationale shown in section 2.2 as well as the findings of (Tsai, 2001; Gilsing, et al., 2008; Dominguez Lacasa \& Shubbak, 2018).

Another interesting finding within the network-embeddedness dimension is that organizations belonging to small-world networks achieved even a higher economic performance than those with high vertex centrality. This highlights the greater importance of the network structure than the positions of individual nodes. Although organizations in small-world networks had, on average, less direct ties to other actors, the structure of their network components provided them with high proximity to more actors, albeit indirectly. While Tsai (2001) stressed the role of central network positions in providing organizational units with access to new knowledge developed elsewhere, our results shows that the network clustering structure is even more important as it takes both direct and indirect knowledge paths into consideration.

Finally, Hypothesis 3 suggested a higher positive impact of innovation on economic performance when network embeddedness is high. Figure 7c shows a significant higher turnover for actors with high-quality innovations when they are embedded in small-world networks or when they have central network positions. Therefore, we can confidently accept hypothesis 3 . This finding, along with the discussion of hypothesis $2 \mathrm{a}$, support our thesis that the impact of innovation on economic performance of firms is highly heterogeneous across different network-embeddedness patterns. Furthermore, it sheds the light on the network and innovation patterns that yielded high economic performance in the Chinese PV sector.

The analysis revealed another interesting remark regarding the innovative organizations, whose activities are technologically diversified. Such firms tend to achieve higher economic performance when operating in small networks with low embeddedness. Sourcing external knowledge in technological fields beyond the specialization of a company is widely considered among the main motivations of interfirm collaboration. Accordingly, this tendency can be explained by the fact that having a diversified portfolio of technological activities internally, such firms need less external collaborations.

\section{CONCLUSIONS}

The present research shed light on the technological upgrading of China in PV technology. It analysed the patterns of innovative activities and network embeddedness and their impact on economic performance of leading actors within the Chinese technological system of innovation. Based on several market and patent indicators, the 
paper identified 37 organisations as the main actors in the system. These few actors, however, have a prominent position in the system as they are accountable of more than $60 \%$ of PV production and $41 \%$ of PV patenting activities in China.

Moreover, six different patterns of innovative activity were recognized along with five network embeddedness patterns. Introducing the analytical tool of concurrency matrix, the co-evolution of both dimensions was captured. The results showed a significant effect of the interaction between innovation-capability and network-embeddedness dimensions on the economic performance of organisations. Confirming the literature on single-basis effects, the paper came up with additional insights on the confluence of both dimensions.

Furthermore, the results revealed interesting findings regarding the most significant factors in each dimension. The analysis went further than confirming the positive impact of innovation on economic performance. It shows that the quality of innovation outcomes is even more important than their quantity or diversity.

Taken together, the results show that the combination of high-quality innovation, globalintegration and small-world networks yields in a significantly higher turnover. Accordingly, the results introduce several managerial and policy implications. At the organizational level, it highlights the importance for directors and managerial units to devote greater attention to qualitative R\&D activities, strategic knowledge cooperation, and global integration in order to achieve higher economic performance in the long run. Additionally, at the macroeconomic level, the results suggest some implications for policy makers to consider through innovation policies by supporting the establishment of cross-border collaborations, foreign direct investments, and joint-ventures in order to uphold successful technological upgrading.

Some limitations regarding the lack of involvement of two more elements can be considered as an area for further research. Those are the institutional side of innovation system and the dynamic dimension of network analysis over time.

Overall, the paper attempted to push forward a new field by analysing the confluence of two different dimensions that have long been analysed in single basis. The replication of the research methodology for other technological, national, or regional contexts to test whether similar relationships could be found, would likely contribute to economic and business theories development. Whereas, taking the concurrency aspect into consideration in both management strategies and policy making, clean energy technologies such as PV would reach their ultimate goal of being both competitive and politics independent.

\section{ACKNOWLEDGEMENTS}

The author is immensely thankful to Jutta Günther (University of Bremen), Björn Jindra (Copenhagen Business School), Wolfram Elsner (University of Bremen), Shuanping Dai (University of Duisburg-Essen) and two anonymous reviewers for their valuable comments on earlier versions of the manuscript. 


\section{REFERENCES}

Adeyeye, A. D., Jegede, O. O. \& Akinwale, Y. O., 2013. The impact of technology innovation and R\&D on firms' performance: an empirical analysis of Nigeria's service sector. International Journal of Technological Learning, Innovation and Development, 6(4), pp. 374395.

Ahuja, G., 2000. Collaboration Networks, Structural Holes, and Innovation: A Longitudinal Study. Administrative Science Quarterly, 45(3), pp. 425-455.

Anderberg, M. R., 1973. Cluster Analysis for Applications. New York: Academic Press Inc..

Andries, P. \& Faems, D., 2013. Patenting Activities and Firm Performance:. Journal of Product Innovation Management, 30(6), pp. 1089-1098.

Archibugi, D., 1992. Patenting as an indicator of technological innovation: a review. Science and Public Policy, 19(6), pp. 357-368.

Artz, K., Norman, P., Hatfield, D. \& Cardinal, L., 2010. A Longitudinal Study of the Impact of R\&D, Patents, and Product Innovation on Firm Performance. Journal of Product Innovation Management, 27(5), p. 725-740.

Bastian, M., Heymann, S. \& Jacomy, M., 2009. Gephi: an open source software for exploring and manipulating networks. California, International AAAI Conference on Weblogs and Social Media. p. 361-362.

Breschi, S. \& Malerba, F., 1997. Sectoral Innovation Systems: Technological Regimes, Schumpeterian Dynamics, and Spatial Boundaries. In: C. Edquist, ed. Systems of Innovation: Technologies, Institutions and Organizations. London: Pinter, p. 130-156.

British Petroleum, 2017. BP Statistical Review of World Energy, 66th edition, London: British Petroleum Company.

Brown, L. R., Adams, E., Larsen, J. \& Roney, J. M., 2015. The Great Transition: Shifting from Fossil Fuels to Solar and Wind Energy. New York: W. W. Norton \& Company.

Cainelli, G., Evangelista, R. \& Savona, M., 2006. Innovation and economic performance in services: a firm-level analysis. Cambridge Journal of Economics, 30(3), pp. 435-458.

Carlsson, B. \& Stankiewicz, R., 1991. On the Nature, Function and Composition of Technological Systems. Journal of Evolutionary Economics, 1(2), pp. 93-118.

Crepon, B., Duguet, E. \& Mairessec, J., 1998. Research, innovation, and productivity: an econometric analysis at the firm level. Economics of Innovation and New Technology, 7(2), pp. $115-158$.

Dominguez Lacasa, I. \& Shubbak, M., 2018. Drifting towards innovation: The co-evolution of patent networks, policy, and institutions in China's solar photovoltaics industry. Energy Research \& Social Science, Volume 38, pp. 87-101.

Edquist, C., 1997. Systems of Innovation Approaches - Their Emergence and Characteristics. In: C. Edquist, ed. Systems of Innovation. Technologies, Institutions and Organizations. London: Pinter Publishers, pp. 1-35.

Evangelista, R. \& Vezzani, A., 2010. The economic impact of technological and organizational innovations. A firm-level analysis. Research Policy, 39(10), pp. 1253-1263. 
Franko, L. G., 1989. Global corporate competition: Who's winning, who's losing, and the R\&D factor as one reason why. Strategic Management Journal, Volume 10, p. 449-474.

Freeman, C., 1988. Japan: A new National Innovation Systems?. In: G. Dosi, et al. eds. Technology and economic theory. London: Pinter Publishers, pp. 330-348.

Freeman, C., 2004. Technological infrastructure and international competitiveness. Industrial and Corporate Change, 13(3), p. 541-569.

Freeman, L., 1977. "A set of measures of centrality based upon betweenness". Sociometry, Volume 40, p. 35-41.

Frietsch, R. \& Schmoch, U., 2010. Transnational Patents and International Markets. Scientometrics, 82(1), p. 185-200.

$\mathrm{Fu}, \mathrm{X}$., 2015. Key Determinants of Technological Capabilities for a Green Economy in Emerging Economies. In: R. Vos \& D. Alarcon, eds. The United Nations Series on Development: Technology and Innovation for Sustainable Development. New York: Bloomsbury Academic.

Geroski, P. \& Machin, S., 1992. Do Innovating Firms Outperform Non-Innovators?. Business Strategy Review, Volume 3, p. 79-90.

Gilsing, V. et al., 2008. Network embeddedness and the exploration of novel technologies:. Research Policy, 37(10), pp. 1717-1731.

Goerzen, A. \& Beamish, P. W., 2005. The Effect of Alliance Network Diversity on Multinational Enterprise Performance. Strategic Management Journal, 26(4), pp. 333-354.

Grice, J. \& Iwasaki, M., 2007. A Truly Multivariate Approach to MANOVA. Applied Multivariate Research, 12(3), pp. 199-226.

Günther, J., 2015. Innovation. In: J. Hölscher \& H. Tomann, eds. Palgrave Dictionary of Emerging Markets and Transition Economies. London: Palgrave Macmillan, pp. 360-371.

Hagedoorn, J., 1993. Understanding the rationale of strategic technology partnering: Nterorganizational modes of cooperation and sectoral differences. Strategic Management Journal, 14(5), pp. 371-385.

Hashi, I. \& Stojčić, N., 2013. The impact of innovation activities on firm performance using a multi-stage model: Evidence from the Community Innovation Survey 4. Research Policy, 42(2), pp. 353-366.

Hegedus, S. \& Luque, A., 2010. Achievements and Challenges of Solar Electricity from Photovoltaics . In: S. Hegedus \& A. Luque, eds. Handbook of Photovoltaic Science and Engineering. Chichester: John Wiley \& Sons, pp. 1-38.

Hirschman, A., 1964. The Paternity of an Index. The American Economic Review, 54(5), p. 761.

Hitt, M., Hoskisson, R. \& Kim, H., 1997. International Diversification: Effects on Innovation and Firm Performance in Product-diversified Firms. Academy of Management Journal, 40(4), pp. 767-798.

IBM Corp., 2016. IBM SPSS Statistics for Windows - Version 24.0., Armonk, NY: IBM Corp..

Jackson, M. O., 2008. Social and Economic Networks. New Jersey: Princeton University Press.

Jäger-Waldau, A., 2013. PV Status Report 2013 (JRC Scientific and Policy Report EUR 26118 $E N)$, Ispra: European Commission and DG Joint Research Centre. 
Jindra, B., Dominguez Lacasa, I. \& Radosevic, S., 2015. Dynamics of Technology Upgrading of the Central and East European Countries in a Comparative Perspective: Analysis Based on Patent Data, UCL SSEES Centre for Comparative Economics, February 2015: Economics and Business Working Paper No.135.

Kleinknecht, A., Montfort, K. V. \& Brouwer, E., 2002. The Non-trivial Choice between Innovation Indicators. Economics of Innovation and New Technology, 11(2), pp. 109-121.

Koka, B. \& Prescott, J., 2008. Designing alliance networks: the influence of network position, environmental change, and strategy on firm performance. Strategic Management Journal, 29(6), pp. 639-661.

Krzywinski, M. I. et al., 2009 . Circos: An information aesthetic for comparative genomics. Genome Research, Volume 19, pp. 1639-1645.

Lee, K., 2013. Schumpeterian Analysis of Economic Catch-up, Knowledge, Path-creation and the Middle-Income Trap. Cambridge: Cambridge University Press.

Lester, D., 1998. Critical success factors for new product development. Research Technology Management, , 41(1), pp. 36-43.

Leten, B., Belderbos, R. \& Van Looy, B., 2007. Technological Diversification, Coherence, and Performance of Firms. Journal of Product Innovation Management, 24(6), pp. 567-579.

Lu, J. W. \& Beamish, P. W., 2004. International Diversification and Firm Performance: The SCurve Hypothesis. The Academy of Management Journal, 47(4), pp. 598-609.

Lundvall, B., 1992. National Systems of Innovation: Towards a Theory of Innovation and Interactive Learning. London: Pinter.

MacDonald, S., 2004. When means become ends: considering the impact of patent strategy on innovation. Information Economics and Policy, 16(1), pp. 135-158.

Malerba, F. \& Orsenigo, L., 1997. Technological Regimes and Sectoral Patterns of Innovative Activities. Industrial and Corporate Change, 6(1), pp. 83-117.

Marigo, N., 2007. The Chinese Silicon Photovoltaic Industry and Market: A Critical Review of Trends and Outlook. Progress in Photovoltaics: Research and Applications, Volume 15, p. $143-162$.

Mertens, K., 2014. Photovoltaics : fundamentals, technology and practice. Chichester: John Wiley \& Sons.

Mints, P., 2014. Top Ten PV Manufacturers from 2000 to Present: A Pictorial Retrospective. Renewable Energy World. [Online] Available at: http://www.renewableenergyworld.com/articles/2014/01/top-ten-pv-manufacturers-from2000-to-present-a-pictorial-retrospective.html [Accessed 24 September 2017].

Mooi, E. \& Sarstedt, M., 2010. Cluster Analysis. In: A Concise Guide to Market Research. Berlin, Heidelberg: Springer-Verlag, pp. 237-284.

Pavitt, K., 1963. Research, Innovation and Economic Growth. Nature, Volume 200, pp. 206-210.

Pavitt, K., 1985. Patent Statistics as Indicators of Innovative Activities: Possibilities and Problems. Seientometrics, 7(1-2), pp. 77-99. 
Powell, W., Koput, K. \& Smith-Doerr, L., 1996. Interorganizational collaboration and the locus of innovation: networks of learning in biotechnology. Administrative Science Quarterly , 41(1), pp. 116-145.

Radosevic, S. \& Yoruk, E., 2016. Why do we need a theory and metrics of technology upgrading?. Asian Journal of Technology Innovation, 24(sup1), pp. 8-32.

Roselund, C., 2016. 2015 Poly and wafer rankings. PV Magazine, Volume 4/2016, pp. 74-77.

Rowley, T., Behrens, D. \& Krackhardt, D., 2000. Redundant governance structures: an analysis of structural and relational embeddedness in the steel and semiconductor industries. Strategic Management Journal, 21(3), pp. 369-386.

Sampson, R., 2007. R\&D Alliances and Firm Performance: The Impact of Technological Diversity and Alliance Organization on Innovation. Academy of Management Journal, 50(2), pp. 364-386.

Sawang, S., Zhou, Y. \& Yang, X., 2017. Does institutional context matter in building innovation capability?. International Journal of Technological Learning, Innovation and Development, 9(2), pp. 153-168.

Schmidt, J. B., 1995. New product myopia. Journal of Business \& Industrial Marketing, 10(1), pp. 23-33.

Schumpeter, J. A., 1934. Theory of Economic Development: An enquiry into Profits, Capital, Interest and the Business Cycle,. Cambridge, MA: Harvard University Press.

Shubbak, M., 2017a. The Technological System of Photovoltaics: Identification and Analysis with Patent Classes. Budapest, The 29th Annual EAEPE Conference, European Association for Evolutionary Political Economy.

Shubbak, M., 2017b. The Technological System of Production and Innovation: The Case of Photovoltaics Technology in China. Berlin, paper presented to Innovation in Emerging Economies Workshop, Berlin 13-14 July.

Silva, G. M., Styles, C. \& Lages, L. F., 2017. Breakthrough innovation in international business: The impact of tech-innovation and market-innovation on performance. International Business Review, 26(2), pp. 391-404.

Stuart, T., 1998. Network positions and propensities to collaborate: an investigation of strategic alliance formation in a high-technology. Administrative Science Quarterly, 43(3), p. 668-698.

Suominen, A., Toivanen, H. \& Seppaenen, M., 2017. Firms' knowledge profiles: Mapping patent data with unsupervised learning. Technological Forecasting \& Social Change, Volume 115, pp. 131-142.

Tsai, W., 2001. Knowledge Transfer in Intraorganizational Networks: Effects of Network Position and Absorptive Capacity on Business Unit Innovation and Performance. Academy of Management Journal, 44(5), pp. 996-1004.

UNEP, EPO \& ICTSD, 2010. Patents and Clean Energy: Bridging the Gap between Evidence and Policy, Final Report, Geneva: United Nations Environment Programme, European Patent Office, and International Centre for Trade and Sustainable Development.

Uzzi, B., 1996. The Sources and Consequences of Embeddedness for The Economic Performance of Organizations: The Network Effect. American Sociological Review, 61(4), pp. 674-698. 
Victor, D. et al., 2017. Prove Paris was more than paper promises. Nature, Volume 548, pp. 2527.

Wang, Y., Assche, A. V. \& Turkina, E., 2018. Antecedents of SME embeddedness in interorganizational networks: Evidence from China's aerospace industry. Journal of Small Business \& Entrepreneurship, 30(1), pp. 53-75.

Yu, Y., Li, H. \& Bao, H., 2016. Price dynamics and market relations in solar photovoltaic silicon feedstock trades. Renewable Energy, Volume 86, pp. 526-542.

Zahra, S. A. \& George, G., 2002. Absorptive Capacity: A Review, Reconceptualization, and Extension. The Academy of Management Review, 27(2), pp. 185-203. 
Table A1: The Main Actors in PV Technological Innovation System in China

\begin{tabular}{|c|c|c|c|c|c|c|c|c|}
\hline & Actor & Type & Ctry & $\begin{array}{l}\text { Est. } \\
\text { Yr. }\end{array}$ & $\begin{array}{l}\text { Turnover } \\
\text { [mill. \$] }\end{array}$ & $\begin{array}{l}\text { Empl. } \\
\text { [th.]. }\end{array}$ & $\begin{array}{l}\text { TN } \\
\text { Pat }\end{array}$ & Specialization \\
\hline 1 & Siemens AG & COM & $\mathrm{DE}$ & 1847 & 89,059 & 351.0 & 4 & electronics \\
\hline 2 & Yingli Energy Ltd ${ }^{a, c}$ & $\mathrm{COM}$ & $\mathrm{CN}$ & 2006 & 1,535 & 14.5 & 11 & c-Si cells \\
\hline 3 & Shanghai Convertergy Ltd ${ }^{\mathrm{c}}$ & $\mathrm{COM}$ & $\mathrm{CN}$ & 2010 & 3 & 0.05 & 7 & electronics \\
\hline 4 & Uni Tsinghua & EDU & $\mathrm{CN}$ & 1911 & 1,850 & 7.2 & 12 & education, research \\
\hline 5 & Du Pont & $\mathrm{COM}$ & US & 1915 & 25,268 & 52.0 & 19 & c-Si, TF, $3 \mathrm{G}$ cells \\
\hline 6 & Wuxi Suntech Power Ltd ${ }^{\mathrm{a}, \mathrm{c}}$ & $\mathrm{COM}$ & $\mathrm{CN}$ & 2001 & 621 & 2.0 & 27 & c-Si cells \\
\hline 7 & Sandisk Information Tech. & $\mathrm{COM}$ & US & 1988 & 5,570 & 8.8 & 5 & electronics \\
\hline 8 & Gen Electric & $\mathrm{COM}$ & US & 1892 & 117,184 & 305.0 & 14 & electronics \\
\hline 9 & Xiamen Sanan Opto Tech. & $\mathrm{COM}$ & $\mathrm{CN}$ & 1993 & 741 & 7.1 & 14 & LED, 3G cells \\
\hline 10 & Honeywell Int Inc & $\mathrm{COM}$ & US & 1885 & 30,000 & 125.0 & 9 & chemicals, cells \\
\hline 11 & State Grid Corp China & GOV & $\mathrm{CN}$ & 2003 & 38,286 & 927.8 & 16 & electricity trans. \\
\hline 12 & China Elect. Power Res Inst & INST & $\mathrm{CN}$ & 1951 & n.a. & 1.8 & 8 & research \\
\hline 13 & BYD Co Ltd & $\mathrm{COM}$ & $\mathrm{CN}$ & 1995 & 12,252 & 200.0 & 39 & automobile, cells \\
\hline 14 & Rongxin Power Electronics & $\mathrm{COM}$ & GB & 2012 & 1,000 & 2.6 & 9 & energy, electronics \\
\hline 15 & Tyco Electronics Co & $\mathrm{COM}$ & $\mathrm{CH}$ & 1941 & 12,200 & 75.0 & 7 & electronics, panels \\
\hline & Inst. Microelec. CAS & EDU & $\mathrm{CN}$ & 1928 & 65 & 0.8 & 13 & education, research \\
\hline 17 & ZTE Corp & $\mathrm{COM}$ & $\mathrm{CN}$ & 1985 & 12,220 & 69.1 & 6 & panels, electronics \\
\hline 18 & Trina Solar Energy ${ }^{\mathrm{a}, \mathrm{c}}$ & $\mathrm{COM}$ & $\mathrm{CN}$ & 2006 & 3,036 & 13.6 & 23 & c-Si cells \\
\hline 19 & Oceans King Lighting ${ }^{c}$ & $\mathrm{COM}$ & $\mathrm{CN}$ & 1995 & 136 & 2.7 & 29 & organic cells \\
\hline 20 & Canadian Solar CSI Cells a,c & $\mathrm{COM}$ & $\mathrm{CA}$ & 2001 & 3,468 & 9.0 & 13 & c-Si cells \\
\hline 21 & BOE Technology Group & $\mathrm{COM}$ & $\mathrm{CN}$ & 1993 & 7,448 & 42.8 & 17 & display, electronics \\
\hline 22 & AU Optronics Corp & $\mathrm{COM}$ & TW & 2001 & 11,018 & 62.8 & 49 & c-Si cells, panels \\
\hline 23 & Shenzhen China Star Opt & $\mathrm{COM}$ & $\mathrm{CN}$ & 2009 & 2,520 & 7.5 & 14 & electronics \\
\hline 24 & Omnivision Tech. & $\mathrm{COM}$ & US & 1995 & 1,379 & 2.2 & 11 & panels \\
\hline 25 & Silicon China HK & COM & $\mathrm{CN}$ & 1992 & 15 & 0.1 & 8 & c-Si cells, panels \\
\hline 26 & Huawei Tech Co Ltd & $\mathrm{COM}$ & $\mathrm{CN}$ & 1987 & 59,466 & 140.0 & 9 & electronics \\
\hline 27 & Uni Beijing & EDU & $\mathrm{CN}$ & 1898 & 1,290 & 8.6 & 8 & education, research \\
\hline 28 & Anhui Everup Green Energy ${ }^{c}$ & $\mathrm{COM}$ & $\mathrm{CN}$ & 2001 & 27 & 0.2 & 5 & panels, electronics, \\
\hline 29 & 3M Innovative Prop. Co & $\mathrm{COM}$ & US & 1902 & 30,274 & 89.8 & 4 & electronics, storage \\
\hline 30 & Jinkosolar Co Ltd ${ }^{\mathrm{a}, \mathrm{c}}$ & $\mathrm{COM}$ & $\mathrm{CN}$ & 2006 & 2,477 & 14.0 & 1 & c-Si cells \\
\hline & Ja Solar Co Ltd a,c & $\mathrm{COM}$ & $\mathrm{CN}$ & 2005 & 2,084 & 12.6 & 2 & c-Si cells \\
\hline & Renesola Ltd ${ }^{\mathrm{b}, \mathrm{c}}$ & $\mathrm{COM}$ & $\mathrm{CN}$ & 2006 & 1,299 & 5.4 & 1 & Si-feedstock, cells \\
\hline 33 & Tbea Xinjiang Sunoasis ${ }^{\text {b,c }}$ & $\mathrm{COM}$ & $\mathrm{CN}$ & 2000 & 1,046 & 5.0 & 1 & Si-feedstock \\
\hline 34 & LDK Solar Hi-Tech Ltd ${ }^{b, c}$ & $\mathrm{COM}$ & $\mathrm{CN}$ & 2005 & 3,490 & 13.3 & 2 & Si-feedstock \\
\hline & GCL-Poly Energy ${ }^{b, c}$ & $\mathrm{COM}$ & $\mathrm{CN}$ & 2006 & 4,546 & 17.7 & 0 & Si-feedstock \\
\hline & Daqo Group Co Ltd ${ }^{\text {b,c }}$ & $\mathrm{COM}$ & $\mathrm{CN}$ & 1965 & 2,638 & 10.0 & 0 & Si-feedstock \\
\hline & Hareon Solar Technology ${ }^{a, c}$ & $\mathrm{COM}$ & $\mathrm{CN}$ & 2000 & 933 & 6.1 & 0 & Poly-Si cells \\
\hline
\end{tabular}

Actors in this table are sorted according to their appearance in PATSTAT 2015b database.

Actors 1-34 were involved in co-patenting network components accountable for $41 \%$ of the Chinese TN patent applications in PV technologies.

a. Those seven firms were accountable for 34\% of the global c-Si PV cell production during 2010-2015 ( $60 \%$ of the Chinese production).

b. Those five firms were accountable for 31\% of the global Si-feedstock production during 2010-2015 (more than $90 \%$ of the Chinese production).

c. The business of those fifteen firms are solely focused on PV energy sector. 
Table A2: Two-way MANOVA Analysis for INNO*NET Concurrency

\begin{tabular}{|c|c|c|c|c|c|c|}
\hline Source & $\begin{array}{l}\text { Dependent } \\
\text { Variable }\end{array}$ & $\begin{array}{l}\text { Type III Sum } \\
\text { of Squares }\end{array}$ & Df & $\begin{array}{c}\text { Mean } \\
\text { Square }\end{array}$ & $\mathbf{F}$ & Sig. \\
\hline \multirow{4}{*}{$\begin{array}{l}\text { Corrected } \\
\text { Model }\end{array}$} & age* & $4.43 \mathrm{E}+04^{\mathrm{a}}$ & 15 & $2.95 \mathrm{E}+03$ & 2.179 & $0.052 *$ \\
\hline & turnover** & $1.90 \mathrm{E}+10^{\mathrm{b}}$ & 15 & $1.27 \mathrm{E}+09$ & 5.935 & $0.000 * *$ \\
\hline & employees & $5.19 \mathrm{E}+05^{\mathrm{c}}$ & 15 & $3.46 \mathrm{E}+04$ & 1.466 & 0.209 \\
\hline & productivity** & $5.14 \mathrm{E}+05^{\mathrm{d}}$ & 15 & $3.43 \mathrm{E}+04$ & 2.942 & $0.013^{* *}$ \\
\hline \multirow[t]{4}{*}{ Intercept } & $\operatorname{age}^{* *}$ & $3.72 \mathrm{E}+04$ & 1 & $3.72 \mathrm{E}+04$ & 27.462 & $0.000^{* *}$ \\
\hline & turnover** & $3.32 \mathrm{E}+09$ & 1 & $3.32 \mathrm{E}+09$ & 15.519 & $0.001^{* *}$ \\
\hline & employees** & $1.17 \mathrm{E}+05$ & 1 & $1.17 \mathrm{E}+05$ & 4.939 & $0.038^{* *}$ \\
\hline & productivity** & $1.50 \mathrm{E}+06$ & 1 & $1.50 \mathrm{E}+06$ & 128.515 & $0.000 * *$ \\
\hline \multirow[t]{4}{*}{ INNO } & age & $2.53 \mathrm{E}+03$ & 4 & $6.32 \mathrm{E}+02$ & 0.466 & 0.760 \\
\hline & turnover** & $2.96 \mathrm{E}+09$ & 4 & $7.40 \mathrm{E}+08$ & 3.465 & $0.026^{* *}$ \\
\hline & employees & $1.12 \mathrm{E}+05$ & 4 & $2.80 \mathrm{E}+04$ & 1.186 & 0.347 \\
\hline & productivity & $9.46 \mathrm{E}+04$ & 4 & $2.37 \mathrm{E}+04$ & 2.030 & 0.129 \\
\hline \multirow[t]{4}{*}{ NET } & age* & $1.13 \mathrm{E}+04$ & 3 & $3.77 \mathrm{E}+03$ & 2.778 & $0.068^{*}$ \\
\hline & turnover** & $3.57 \mathrm{E}+09$ & 3 & $1.19 \mathrm{E}+09$ & 5.575 & $0.006^{* *}$ \\
\hline & employees & $6.48 \mathrm{E}+04$ & 3 & $2.16 \mathrm{E}+04$ & 0.914 & 0.452 \\
\hline & productivity** & $1.36 \mathrm{E}+05$ & 3 & $4.52 \mathrm{E}+04$ & 3.877 & $0.025^{* *}$ \\
\hline \multirow{4}{*}{$\begin{array}{l}\text { INNO * } \\
\text { NET }\end{array}$} & age* & $1.99 \mathrm{E}+04$ & 7 & $2.84 \mathrm{E}+03$ & 2.097 & $0.092 *$ \\
\hline & turnover** & $8.42 \mathrm{E}+09$ & 7 & $1.20 \mathrm{E}+09$ & 5.628 & $0.001^{* *}$ \\
\hline & employees & $2.20 \mathrm{E}+05$ & 7 & $3.14 \mathrm{E}+04$ & 1.331 & 0.287 \\
\hline & productivity** & $2.32 \mathrm{E}+05$ & 7 & $3.32 \mathrm{E}+04$ & 2.847 & $0.031^{* *}$ \\
\hline \multirow[t]{4}{*}{ Error } & age & $2.71 \mathrm{E}+04$ & 20 & $1.36 \mathrm{E}+03$ & & \\
\hline & turnover & $4.27 \mathrm{E}+09$ & 20 & $2.14 \mathrm{E}+08$ & & \\
\hline & employees & $4.72 \mathrm{E}+05$ & 20 & $2.36 \mathrm{E}+04$ & & \\
\hline & productivity & $2.33 \mathrm{E}+05$ & 20 & $1.17 \mathrm{E}+04$ & & \\
\hline \multirow[t]{4}{*}{ Total } & age & $1.30 \mathrm{E}+05$ & 36 & & & \\
\hline & turnover & $2.99 \mathrm{E}+10$ & 36 & & & \\
\hline & employees & $1.18 \mathrm{E}+06$ & 36 & & & \\
\hline & productivity & $2.84 \mathrm{E}+06$ & 36 & & & \\
\hline \multirow{4}{*}{$\begin{array}{l}\text { Corrected } \\
\text { Total }\end{array}$} & age & $7.14 \mathrm{E}+04$ & 35 & & & \\
\hline & turnover & $2.33 \mathrm{E}+10$ & 35 & & & \\
\hline & employees & $9.92 \mathrm{E}+05$ & 35 & & & \\
\hline & productivity & $7.48 \mathrm{E}+05$ & 35 & & & \\
\hline
\end{tabular}

a. $\mathrm{R}$ Squared $=.620$ (Adjusted R Squared $=.336$ )

b. R Squared $=.817$ (Adjusted R Squared $=.679)$

c. $\mathrm{R}$ Squared $=.524$ (Adjusted R Squared $=.166$ )

d. R Squared $=.688($ Adjusted R Squared $=.454)$

*. Significant at the 0.1 level.

**. Significant at the 0.05 level. 


\section{NOTES}

${ }^{1}$ See for instance, the decision of US president Donald Trump in June 2017 to withdraw the United States from the 2015 Paris climate agreement and its impact on the federal government plans and policies (Victor, et al., 2017).

${ }^{2}$ From that perspective, the present paper can be considered as an attempt to push this area of research forward by studying the cross interaction between innovation capability and network embeddedness and its impact on economic performance.

${ }^{3}$ To make the forward citation index comparable across patent applications with different priority dates, the number of applications citing a patent is divided by the number of years elapsed since the patent has been filed.

${ }^{4}$ Network indicators are based on (Dominguez Lacasa \& Shubbak, 2018), where social network analysis was conducted using Gephi 0.9.1 software (Bastian, et al., 2009). For detailed explanation of network analysis and indicators, see (Jackson, 2008).

${ }^{5}$ The characteristics of network and innovation clusters are shown in the left and bottom sides respectively. The significant feature of each cluster is stated in bold. 